\title{
Ca' Granda, Hortus simplicium: Restoring an Ancient Medicinal Garden of XV-XIX Century in Milan (Italy)
}

\author{
Martina Bottoni ${ }^{1,2, \dagger}$, Fabrizia Milani ${ }^{1,2,+}$ (⿺) , Paolo M. Galimberti ${ }^{3}$, Lucia Vignati ${ }^{4}$, Patrizia Luise Romanini ${ }^{1,2}$, \\ Luca Lavezzo $^{1,2}$, Livia Martinetti ${ }^{5}\left(\mathbb{D}\right.$, Claudia Giuliani ${ }^{1,2, *}$ and Gelsomina Fico ${ }^{1,2}$ \\ 1 Department of Pharmaceutical Sciences, University of Milan, Via Mangiagalli 25, 20133 Milan, Italy; \\ martina.bottoni@unimi.it (M.B.); fabrizia.milani@unimi.it (F.M.); \\ patrizialuise.romanini@studenti.unimi.it (P.L.R.); luca.lavezzo@studenti.unimi.it (L.L.); \\ gelsomina.fico@unimi.it (G.F.) \\ 2 Ghirardi Botanic Garden, Department of Pharmaceutical Sciences, University of Milan, Via Religione 25, \\ 25088 Toscolano Maderno, Italy \\ 3 Fondazione IRCCS Ca' Granda Ospedale Maggiore Policlinico, Via Francesco Sforza 28, 20122 Milan, Italy; \\ archivio@policlinico.mi.it \\ 4 Landscape Ecomuseum of Parabiago, P.za della Vittoria 7, 20015 Milan, Italy; \\ lucia.vignati@comune.parabiago.mi.it \\ 5 Department of Agricultural and Environmental Sciences-Production, Landscape, Agroenergy, \\ University of Milan, Via Celoria 2, 20133 Milan, Italy; livia.martinetti@unimi.it \\ * Correspondence: claudia.giuliani@unimi.it \\ + These authors have contributed equally to this work.
}

\section{check for} updates

Citation: Bottoni, M.; Milani, F.; Galimberti, P.M.; Vignati, L.; Romanini, P.L.; Lavezzo, L.; Martinetti, L.; Giuliani, C.; Fico, G. Ca' Granda, Hortus simplicium: Restoring an Ancient Medicinal Garden of XV-XIX Century in Milan (Italy). Molecules 2021, 26, 6933. https:// doi.org/10.3390/molecules26226933

Academic Editors: Luigi Menghini, Angela Bisio and Maria Pia Argentieri

Received: 23 October 2021

Accepted: 12 November 2021

Published: 17 November 2021

Publisher's Note: MDPI stays neutral with regard to jurisdictional claims in published maps and institutional affiliations.

Copyright: (c) 2021 by the authors Licensee MDPI, Basel, Switzerland. This article is an open access article distributed under the terms and conditions of the Creative Commons Attribution (CC BY) license (https:/ / creativecommons.org/licenses/by/ $4.0 /)$.

\begin{abstract}
This work is based on the study of 150 majolica vases dated back to the mid XVII century that once preserved medicinal remedies prepared in the ancient Pharmacy annexed to the Ospedale Maggiore Ca' Granda in Milan (Lombardy, Italy). The Hortus simplicium was created in 1641 as a source of plant-based ingredients for those remedies. The main objective of the present work is to lay the knowledge base for the restoration of the ancient Garden for educational and informative purposes. Therefore, the following complementary phases were carried out: (i) the analysis of the inscriptions on the jars, along with the survey on historical medical texts, allowing for the positive identification of the plant ingredients of the remedies and their ancient use as medicines; (ii) the bibliographic research in modern pharmacological literature in order to validate or refute the historical uses; (iii) the realization of the checklist of plants potentially present in cultivation at the ancient Garden, concurrently with the comparison with the results of a previous in situ archaeobotanical study concerning pollen grains. For the species selection, considerations were made also regarding drug amounts in the remedies and pedoclimatic conditions of the study area. Out of the 150 vases, 108 contained plant-based remedies, corresponding to 148 taxa. The remedies mainly treated gastrointestinal and respiratory disorders. At least one of the medicinal uses was validated in scientific literature for 112 out of the 148 examined species. Finally, a checklist of 40 taxa, presumably hosted in the Hortus simplicium, was assembled.
\end{abstract}

Keywords: Hortus simplicium; ethnobotany; ethnopharmacology; medicinal plants; botanic garden; restoration

\section{Introduction}

Ospedale Maggiore Ca' Granda (Milan, Lombardy, Italy), today known simply as Policlinico, is considered one of the oldest hospitals in all of Italy. Founded in 1456 at the behest of Francesco Sforza, Duke of Milan, and based on a design by the architect Antonio Averlino, its main purpose was to provide free medical care to the poorest inhabitants of the city as well as improve the efficiency of the healthcare system across the diocese territory. For centuries, this institution was considered a model in the construction of many other European hospitals [1]. The building included also a Pharmacy, place of research, 
preparation, and distribution of different remedies, as testified by a historical document from 1470 [2-5]. Between 1640 and 1643, the Hospital commissioned ceramist Michele Valli, from Lodi, to manufacture 575 majolica pots for the ingredients of the annexed Pharmacy, while new supplies of vases were secured over the course of the first half of the XVIII century [6]. At the dawn of World War II, 196 pots were still viable. However, after the bombings, only 150 remained unscathed to this day. Of these, 37 were part of the original production, while the remaining ones were realised during the 1700s. The aforementioned collection is currently preserved by the Service for Cultural Assets of the Policlinico [7]. The vases were used to preserve both single ingredients and complex remedies. These specimens were often plant-based and were processed in the Pharmacy to be administered to the patients of the Hospital. In 1641, a Garden of Simples, annexed to the Hospital, was built. Gardens of Simples, also known as Horti simplicium, are considered to be precursors of the modern Botanic Gardens. Originally, back in the Middle Ages, Gardens of Simples were structures connected to ancient monasteries for the cultivation and study of medicinal plants. Later on, they became more prominent in universities, where the plants were used primarily for educational purposes. In contrast, the Garden of the Ospedale Maggiore $\mathrm{Ca}^{\prime}$ Granda of Milan was annexed to a hospital and the plants therein ended up being directly part of the remedies concocted for the patients [4]. With the emergence of pharmaceutical chemistry in the first half of the XIX century, the ancient Garden gradually lost its relevance as a source of medicinal plants and began to be used as an ornamental green area, no longer intended for the cultivation of medicinal species. During the 1930s, the layout of the Garden was modified due to renovation works of the main building. In the 1960s, additional construction works determined a gradual reduction of the Garden surface area. Today, the area where the ancient Garden stands covers only $680 \mathrm{~m}^{2}, 520$ of which are simple lawns [4].

The work presented herein aims at laying the scientific knowledge basis for the future restoration of the ancient Garden of Simples, in the framework of the historical value and educational enhancement of a little-known cultural heritage in Milan. A multidisciplinary approach of investigation was adopted, beginning from the study of the actually preserved 150 majolica jars. The work included complementary subsequent phases: (1) historical survey, with the purpose of defining the composition of the remedies contained in the jars and their historical medical use, focusing on plant-based ingredients; (2) pharmacological research, performed through the consultation of the current relevant scientific literature, in order to either validate or refute the ancient medicinal uses of the plants surveyed; (3) compilation of a checklist of taxa that were potentially present in cultivation in the ancient Garden of Simples.

\section{Results and Discussion}

\subsection{Inscriptions Analysis and Interpretation}

The 150 jars were categorised into three types (Figure 1): spool albarelli (albarelli a rocchetto, or slender terracotta containers with a short neck and a large opening) of two different sizes (Figure 1a); jugs (orcioli, or pot-bellied containers with a hole at the bottom that allows easy spilling of the contents, Figure 1b); and spheroidal bottles (Figure 1c). The pots are made of white majolica with bear blue decorations and the inscriptions are in old Gothic style and black ink. Each vase is numbered progressively. The inscriptions are written in Latin or vulgar Italian and are for the most part abbreviated, thus making information concerning the ingredients and the types of preparation sometimes hard to discern. 


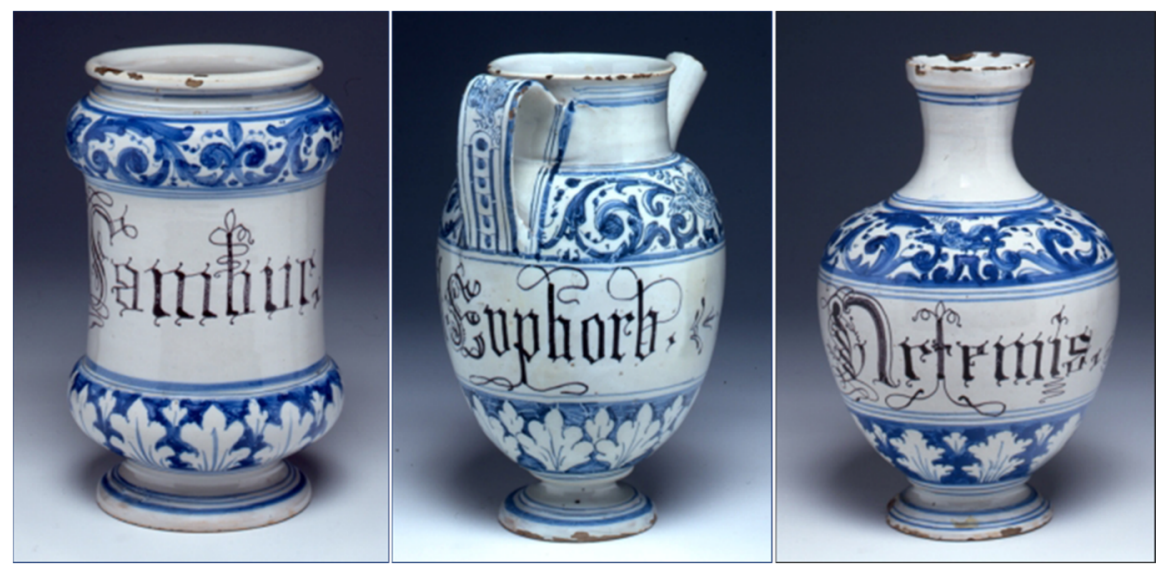

(a)

(b)

(c)

Figure 1. Majolica vases: (a) spool albarello; (b) orciolo; (c) spheroidal bottle. (Images owned by Fondazione IRCCS Ca' Granda Ospedale Maggiore Policlinico, Milan.)

In some cases, the abbreviations were hard to interpret also due to potential spelling mistakes made by the decorator, or to the presence of uncommon and unfamiliar words. As a way of example, we cite vase n. 33, Syrupus d. Duab. Rad., which was the extremely contracted version of the Latin Syrupus de Duabus Radicibus. For these reasons, the inscriptions needed attentive reading. Based on the interpretation of the labels and the origin of the main ingredients, the jars were further categorised as plant-based (108 vases; vase n. 17, which contained as the main ingredient mushrooms belonging to the genus Agaricus, was also included in this category), animal-based (13), mineral-based (8), or unknown origin (21; in these cases, both the deciphering of the inscriptions and the historical survey yielded no usable results). Finally, the plant-based category was subdivided into 15 groups, based on the type of preparation: aqua (27 vases; aqueous extract); syrupus (21; syrup); trochiscus (18; dosage form similar to granules); oleum (12; oleolytes); unguentum (9; ointment); electuarium (6; electuary); pilulae (5; dosage form similar to tablets); mel. ros (2; honey-based composition); pulvis (2; powder); reb/roab (2; condensed syrup); oxymel (2; liquid preparation based on honey and vinegar); diatrum (1; preparation made up of three components); emplastrum (1; poultice); floris (1; flowers); opiatus poter. (1; opium-based preparation). It is worth recalling that the remaining jars represent only a limited part of all the products that could originally be found in the Pharmacy, thus giving us only partial knowledge concerning the remedies used. See Table 1 for details.

Table 1. List of the 108 plant-based vases, with information about vase number (corresponding to the cataloguing number attributed to each vase in the collection preserved at the Service for Cultural Assets of the Policlinico of Milan), original vase inscription, plant ingredients present in the remedy with the indications of the scientific names, and the historical source.

\begin{tabular}{|c|c|c|c|}
\hline $\begin{array}{l}\text { Vase } \\
\text { Number }\end{array}$ & Vase Inscription & Plant Ingredients (Genus/Species) & Historical Source \\
\hline 2 & Aqua Moli & $\begin{array}{l}\text { Mythological plant (still unknown) useful for } \\
\text { potions and spells }\end{array}$ & \\
\hline 3 & Aqua Aequi. & Equisetum arvense $\mathrm{L}$. & [8] \\
\hline 4 & Trochiscus Alhandal. & Citrullus colocynthis (L.) Schrad. & [9] \\
\hline 6 & Unguentum Lapatÿ & $\begin{array}{l}\text { Cinnamomum camphora (L.) J. Presl, Rosa spp., } \\
\text { Rumex conglomeratus Murray, Viola spp. }\end{array}$ & {$[10,11]$} \\
\hline 7 & Unguentum Agrippae & $\begin{array}{l}\text { Bryonia spp., Drimia maritima (L.) Stern, Ecballium } \\
\text { elaterium (L.) A. Rich., Eryngium maritimum L., } \\
\text { Pistacia lentiscus L., Sambucus ebulus L. }\end{array}$ & {$[10,11]$} \\
\hline
\end{tabular}


Table 1. Cont.

\begin{tabular}{cc}
\hline $\begin{array}{c}\text { Vase } \\
\text { Number }\end{array}$ & Vase Inscription \\
\hline 9 & Electuarium Diacurcuma \\
& \\
10 & Unguentum Rosati \\
11 & Trochiscus Absÿnthi \\
13 & Trochiscus d. Myrtha. \\
14 & Conserva Hamech. \\
16 & Trochiscus de Agarici \\
15 & Oleum Nucis. mÿrist. \\
\end{tabular}

Oleum Sup. hord.

Oxymel Scyll.

Syrupus rosatus solutus cum fumaria

Oleum Spica.

Syrupus d. Pomis.s.

Oleum Mastyc.

Acorus calamus L., Artemisia absinthium L., Ceterach officinarum Willd., Cinnamomum verum J. Presl, Commiphora gileadensis (L.) C. Chr., Commiphora myrra Nees, Crocus spp. or Crocus sativus L., Curcuma longa L., Cyperus esculentus L., Daucus carota L., Eupatorium cannabinum L.,

Glycyrrhiza glabra L., Lavandula dentata L., Papaver somniferum L., Pimpinella anisum L., Rheum

officinale L., Rubia tinctorum L., Teucrium scordium L., Valeriana spp.

Prunus dulcis (Mill.) D.A. Webb, Rosa spp. Artemisia absinthium L., Asarum europeum L. Lavandula dentata L., Rosa spp. Myrtus communis L.

Artemisia absenthium L., Citrullus colocynthis (L.) Schrad., Pimpinella anisum L., Polypodium vulgare L., Prunus domestica L., Rosa spp., Thymus spp., Viola spp.

Althaea officinalis L., Anethum graveolens L., Myristica fragrans Houtt., Prunus dulcis (Miller) D.A. Webb, Rosmarinus officinalis L. Equisetum arvense L.

Agaricus campestris L., Agaricus bisporus (J.E.

Lange) Imbach, Zingiber officinale Roscoe Myristica fragrans Houtt.

Achillea millefolium L., Acorus calamus L., Alpinia galanga (L.) Willd., Apium graveolens L., Asparagus officinalis L., Athamanta turbith (L.) Brot., Carum carvi L., Convolvulus scammonia L., Crocus spp. or Crocus satious L., Dianthus Caryophyllus L., Elettaria cardamomum (L.) Maton, Euphorbia esula L., Foeniculum vulgare Mill., Iris tuberosa L., Lavandula dentata L., Myristica fragrans Houtt., Piper longum L., Rosa spp., Ruscus aculeatus L., Saxifraga spp., Zingiber officinale Roscoe Borago officinalis L.

Aloe spp., Agaricus bisporus (J.E. Lange) Imbach or Agaricus campestris L., Rosa spp.

Aloe spp., Capparis spinosa L., Citrullus colocynthis (L.) Schrad., Commiphora myrrha (Nees) Engl., Convolvulus scammonia L., Cyclamen hederifolium Aiton, Daphne mezereum L., Dryopteris filix-mas (L.) Schott, Ecballium elaterium (L.) A. Rich., Euphorbia spp., Ferula persica Willd., Iris tuberosa L., Lavandula dentata L., Matricaria chamomilla L., Piper nigrum L., Polypodium vulgare L., Prunus dulcis (Mill.) D.A. Webb, Sambucus ebulus L., Tamarix gallica L., Vitis vinifera L., Zingiber officinale Roscoe Hordeum vulgare L. Drimia maritima (L.) Stearn Fumaria officinalis L., Rosa spp.

Lavandula dentata L., Sesamum indicum L.

Malus domestica (Suckow) Borkh., Prunus dulcis (Mill.) D.A. Webb Pistacia lentiscus L. Myrtus communis L. 
Table 1. Cont.

\begin{tabular}{|c|c|c|c|}
\hline $\begin{array}{l}\text { Vase } \\
\text { Number }\end{array}$ & Vase Inscription & Plant Ingredients (Genus/Species) & Historical Source \\
\hline 33 & Syrupus d. Duab. rad. & $\begin{array}{l}\text { Foeniculum vulgare Mill., Petroselinum crispum } \\
\text { (Mill.) Fuss }\end{array}$ & [25] \\
\hline 34 & Oleum Absinthÿ & Artemisia absinthium $\mathrm{L}$. & [26] \\
\hline 35 & Syrupus heder. terres. & Glechoma hederacea L., Rosa spp. & {$[27]$} \\
\hline 36 & Oleum Lil. alb. q.pl. & Lilium candidum L. & [28] \\
\hline 41 & Electuarium Diaccatol. & Citrullus colocynthis (L.) Schrad. & [29] \\
\hline 44 & Unguentum Citrini & $\begin{array}{l}\text { Boswellia serrata Roxb. ex Colebr., Citrus medica L., } \\
\text { Cinnamomum camphora (L.) J. Presl }\end{array}$ & [30] \\
\hline 45 & Trochiscus d. Cappar. & $\begin{array}{l}\text { Acorus calamus L., Agrimonia eupatoria L., } \\
\text { Aristolochia rotunda L., Asplenium scolopendrum L., } \\
\text { Capparis spinosa L., Clinopodium nepeta subsp. } \\
\text { glandulosum (Req.) Govaerts, Cyperus esculentus } \\
\text { L., Dorema ammoniacum D. Don, Nigella damascena } \\
\text { L., Prunus dulcis (Miller) D.A. Webb, Ruta } \\
\text { graveolens L., Vitex agnus-castus L. }\end{array}$ & [9] \\
\hline 46 & Pilulae Fetid. & Narthex asafoetida Falc. ex Lindl. & [31] \\
\hline 48 & Electuarium Diascord. & $\begin{array}{l}\text { Achillea millefolium L., Angelica spp., Centaurea } \\
\text { benedicta (L.) L., Galega officinalis L., Potentilla } \\
\text { erecta (L.) Raeusch., Ruta graveolens L., Sambucus } \\
\text { nigra L., Scorzonera spp., Teucrium scordium L. } \\
\text { Acacia senegal (L.) Willd., Astragalus bustillosii } \\
\text { Clos, Cichorium endivia L., Cucumis melo L., }\end{array}$ & {$[32,33]$} \\
\hline 50 & Diatrium. santal. & $\begin{array}{l}\text { Glycyrrhiza glabra L., Portulaca oleracea L., } \\
\text { Pterocarpus santalinus L.f., Rosa spp., Rhaponticum } \\
\text { scariosum Lam., Santalum album L., Viola spp. } \\
\text { Artemisia absinthium L., Commiphora myrrha (Nees) }\end{array}$ & [9] \\
\hline 51 & Trochiscus de Mirra & $\begin{array}{c}\text { Engl., Cuminum cynimum L., Lupinus albus L., } \\
\text { Rubia tinctorum L. }\end{array}$ & [9] \\
\hline 53 & Oleum Mitridat. d. & $\begin{array}{l}\text { Different species, exact recipe not yet known } \\
\text { Acorus calamus L., Carum carvi L., Cuminum } \\
\text { cyminum L., Laurus nobilis L., Nigella sativa L., }\end{array}$ & \\
\hline 54 & Electuarium d. Bac. laur. & $\begin{array}{c}\text { Origanum vulgare L., Piper longum L., Piper nigrum } \\
\text { L., Prunus dulcis (Miller) D.A. Webb, Ruta } \\
\text { graveolens L. }\end{array}$ & [9] \\
\hline 55 & Opiatus poter. & Papaver somniferum L., Veronica spp & {$[34]$} \\
\hline 57 & Trochiscus Aland. & Citrullus colocynthis (L.) Schrad. & [9] \\
\hline 60 & Extractus Vissi. querc. & $\begin{array}{l}\text { Loranthus europaeus Jacq. } \\
\text { Althaea officinalis L., Larix spp. or Pinus spp. or }\end{array}$ & [35] \\
\hline 61 & Unguentum Dialthee sub. & $\begin{array}{c}\text { Picea spp. (turpentine), Larix spp. or Pinus spp. } \\
\text { or Picea spp. (rosin), Linum usitatissimum L., } \\
\text { Trigonella foenum-graecum L. }\end{array}$ & {$[36,37]$} \\
\hline 62 & Reb. Sambuc. & Sambucus nigra L. & {$[38]$} \\
\hline 64 & Conserva Absinth. & Artemisia absinthium L. & {$[39,40]$} \\
\hline 68 & Unguentum Diagridium & $\begin{array}{l}\text { Convolvulus scammonia L. } \\
\text { Boswellia serrata Roxb. ex Colebr. Commiphora }\end{array}$ & Not Found \\
\hline 69 & Pilulae de Cinoglo. & $\begin{array}{l}\text { myrrha (Nees) Engl., Crocus spp. or Crocus sativus } \\
\text { L., Cynoglossum officinale L., Hyoscyamus niger L., } \\
\text { Papaver somniferum L., Viola spp. }\end{array}$ & [9] \\
\hline 75 & Extractus haed. terrest. & Glechoma hederacea L. & [41] \\
\hline 76 & Unguentum Lapat. & $\begin{array}{l}\text { Cinnamomum camphora (L.) J. Presl, Rosa spp., } \\
\text { Rumex conglomeratus Murray, Viola spp. }\end{array}$ & {$[10,11]$} \\
\hline 78 & Emplastrum crustae panis $\mathrm{m}$. & $\begin{array}{l}\text { Mentha spp., Pistacia lentiscus L., Pterocarpus } \\
\text { santalinus L.f., Santalum album L., Triticum } \\
\text { aestivum L. subsp. aestivum, Vitis vinifera L. }\end{array}$ & [9] \\
\hline 79 & Roab. Sambuc. & Sambucus nigra $\mathrm{L}$. & {$[38]$} \\
\hline
\end{tabular}


Table 1. Cont.

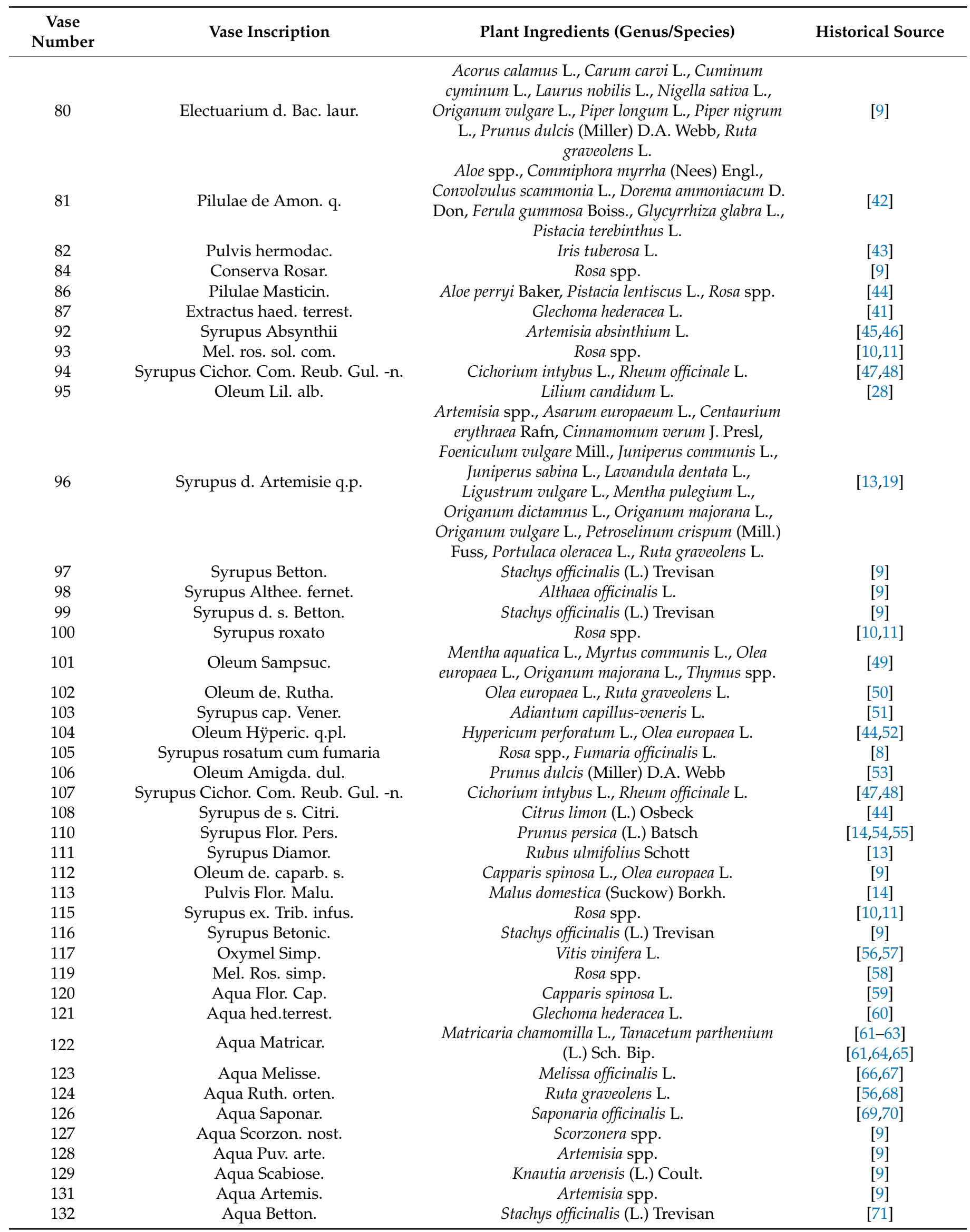


Table 1. Cont.

\begin{tabular}{|c|c|c|c|}
\hline $\begin{array}{l}\text { Vase } \\
\text { Number }\end{array}$ & Vase Inscription & Plant Ingredients (Genus/Species) & Historical Source \\
\hline 133 & Aqua Petasit. & $\begin{array}{l}\text { Petasites hybridus (L.) G. Gaertn., } \\
\text { B. Mey. \& Scherb. }\end{array}$ & [72] \\
\hline 134 & Aqua Flor. samb. & Sambucus nigra L. & [73-75] \\
\hline 135 & Aqua Tot. citri. & Citrus medica L. & {$[76,77]$} \\
\hline 136 & Aqua Pimpinell. & Pimpinella saxifraga L. & {$[62]$} \\
\hline 137 & Aqua Mil. fol. & Achillea millefolium $\mathrm{L}$. & {$[62]$} \\
\hline 139 & Aqua Card. bend. & Centaurea benedicta (L.) L. & [78] \\
\hline 140 & Aqua Cent. min. & Centaurium erythraea Rafn. & [9] \\
\hline 141 & Aqua Scabiose. & Knautia arvensis (L.) Coult. & [9] \\
\hline 142 & Aqua Gland. persic. & $\begin{array}{l}\text { Prunus persica (L.) Batsch, Vitis vinifera L. } \\
\text { Agrimonia eupatoria L., Borago officinalis L., }\end{array}$ & {$[10,11]$} \\
\hline 143 & Aqua Pulmon. & $\begin{array}{c}\text { Pulmonaria officinalis L., Rosa spp., Salvia officinalis } \\
\text { L., Sanguisorba officinalis L., Symphytum officinale } \\
\text { L., Veronica spp. }\end{array}$ & [9] \\
\hline 144 & Aqua Buglos. & Anchusa officinalis L. & {$[27,54]$} \\
\hline 145 & Aqua Flor. lil. alb. & Lilium candidum $\mathrm{L}$. & {$[54,61]$} \\
\hline 146 & Aqua Fumar. & Fumaria officinalis L. & {$[8,47]$} \\
\hline 147 & Flores Lil. Com. & Lilium spp. & [61] \\
\hline 149 & Syrupus de Suc. cit. & Citrus limon (L.) Osbeck & {$[44]$} \\
\hline
\end{tabular}

\subsection{Plant Species in the Remedies and Validation of the Historical Medicinal Use}

A total 108 plant-based remedies were cross-referenced on a wide type of historical sources, such as ancient pharmacopoeias, medical texts, and almanacs published between the XV and the XIX century [8-78]. In this manner, a total of 148 plant taxa, belonging to 58 different botanical families, were found. The complete list is available in Table S1. The most cited families were Apiaceae and Lamiaceae (16 taxa; 10.8\%), Compositae (12; 8.1\%), Rosaceae $(9 ; 6.1 \%)$, and Leguminosae $(7 ; 4.7 \%)$, while the most represented genera were Mentha, Origanum, and Prunus (3 species each) followed by Commiphora (2), Ferula (2), and Pistacia (2).

The historical medicinal uses documented for the 108 plant-based remedies concern the treatment of the following ailments: digestive tract disorders (diarrhoea, constipation, gastritis and ulcers, intestinal parasites; 46 vases); general condition (anti-inflammatory, antipyretics, etc.; 30); respiratory tract infections (cough, mucus, tuberculosis, etc.; 28); nervous system disorders (tonics, relaxants, stimulants, etc.; 23); skin diseases and traumas (scabies and other skin parasites, irritations, wounds, etc.; 21); circulatory/lymphatic system disorders (microcirculation, haemorrhages, spleen inflammation, etc.; 21); gynaecological disorders, obstetric, and puerperal problems (emmenagogue activity, facilitate birth, etc.; 18); urinary tract disorders (kidney stones, diuretics, etc.; 14); musculoskeletal system disorders and traumas (muscle and/or joint pain, arthritis, arthrosis, gout, etc.; 12); 'others' (venereal diseases, other pathologies, leftover from the official medicine of the time; 10); oropharyngeal cavity affections (gingivitis, other inflammations, etc.; 2); afflictions of the ear (otitis, etc.; 2); ophthalmic ailments (inflammations, eye care, etc.; 2). Regarding the plant species used to treat the different pathologies, 83 were ingredients in remedies for digestive tract disorders, 76 for circulatory/lymphatic system disorders, and 69 for respiratory tract infections. See Table 2 for complete details.

The survey of the modern pharmacological literature highlighted that at least one historical therapeutic effect was validated for 112 taxa out of 148. On the contrary, it is noteworthy that the effects reported in literature for Matricaria chamomilla L. were opposite in comparison with the uses documented by the historical sources; specifically, in the past it was used in a laxative remedy [20], while the modern literature referred to antidiarrheal properties [79]. Of the consulted literature contributions, 17 reported different plant parts when compared with the ones used in the past. For example, historical sources cited roots 
and seeds to be used for Asarum europaeum L. [9,13,19], while the current pharmacological studies were focused on the plant aerial parts [80].

Table 2. Categories of the pathologies treated with the 108 plant-based remedies, according to historical sources published between the XV and the XIX century [8-78]. The total number of vase-remedies used for the treatment of each category, along with the total number of plant-based ingredients in the remedies, are reported.

\begin{tabular}{ccc}
\hline Category of Pathology & $\begin{array}{c}\text { Tot. Vases Per } \\
\text { Category }\end{array}$ & $\begin{array}{c}\text { Tot. Species } \\
\text { Per Category }\end{array}$ \\
\hline Digestive tract disorders & 46 & 83 \\
General condition & 30 & 59 \\
Respiratory tract infections & 28 & 69 \\
Nervous system disorders & 23 & 51 \\
Skin diseases and traumas & 21 & 45 \\
Circulatory /lymphatic system disorders & 21 & 76 \\
Gynaecological disorders, obstetric and puerperal problems & 18 & 38 \\
Urinary tract disorders & 14 & 33 \\
Musculoskeletal system disorders and traumas & 12 & 17 \\
Oropher & 10 & 32 \\
Afflictions of the ear & 2 & 9 \\
Ophthalmic ailments & 2 & 3 \\
\hline
\end{tabular}

For each of the taxa found in plant-based remedies, the exhaustive comparison with modern pharmacological literature data was presented hereafter (for the complete dataset, see Table S1): Acacia senegal (L.) Willd., anti-inflammatory [81]; Achillea millefolium L., antibacterial, antiulcer, emmenagogue [82]; Acorus calamus L., antiasthmatic, antidiarrheal, anti-inflammatory, kidney stones, diuretic, hypocholesterolemic [83-86]; Adiantum capillusveneris L., antimicrobial, anti-inflammatory, antipyretic, antiviral [87-90]; Agaricus bisporus (J.E. Lange) Imbach, antibacterial, antiviral, anti-inflammatory, gastritis, stomach disorders, immunomodulant [91,92]; Agrimonia eupatoria L., anti-inflammatory (aerial parts), antioxidant (aerial parts) [93]; Aloe spp., antibacterial, wound healing, airways prophylaxis, laxative, vermifuge [94-98]; Althaea officinalis L., anti-inflammatory, expectorant [99,100]; Anchusa officinalis L., antidiabetic, anti-inflammatory, antioxidant [101]; Anethum graveolens L., antimicrobial, anti-inflammatory, analgesic [102]; Angelica spp., antibacterial, anti-inflammatory, antioxidant, antipyretic, bronchodilator (epigeal part) [103]; Artemisia absinthium L., antibacterial, anthelmintic, antifungal, antiprotozoal, antiviral, antioxidant, anti-inflammatory, antipyretic, analgesic, antiulcer, digestive, immunomodulant, kidneys, wounds, jaundice, neuroprotector [104]; Artemisia spp., hepatoprotector (leaves) [105]; Asarum europaeum L., antialzheimer, antitumoral (aerial parts) [80,106]; Asparagus officinalis L., laxative [107]; Asplenium scoloprendrium L., antioxidant [108]; Athamanta turbith (L) Brot., antimicrobial [109]; Borago officinalis L., antiasthmatic (leaves), anti-inflammatory (seeds), antioxidant, spasmolytic (leaves), circulation (leaves) [110-113]; Boswellia serrata Roxb. ex Colebr., antibacterial, antifungal, anti-inflammatory, antioxidant, antimicrobial, asthma, skin wounds, sedative [114-116]; Bryonia spp., anti-inflammatory [117]; Carum carvi L., diuretic, dyspepsia, emmenagogue, gastrointestinal disorders [118,119]; Capparis spinosa L., antimicrobial, anti-inflammatory, hepatoprotector (aerial parts), hypocholesterolemic (fruit), hypoglycaemic (fruit), hypolipidemic (fruit) [120-122]; Centaurium erythraea Rafn., antipyretic, hepatoprotector [123,124]; Centaurea benedicta (L.) L., antischistosomiasis, wounds, antiulcer [125,126]; Ceterach officinarum Willd., antioxidant [127,128]; Cichorium endivia L., antioxidant (hypogeal parts), hepatoprotector $[129,130]$; Citrus medica L., antibacterial [131]; Cinnamomum camphora (L.) J. Presl, antifungal, anti-inflammatory, antiparasitic [132-134]; Cinnamomum verum J. Presl, airways, gastrointestinal disorders, strengthens the nervous system [135-137]; Citrullus colocynthis (L.) Schrad., anti-inflammatory [138]; Commiphora gileadensis (L.) C. Chr., antibacterial [139]; Commiphora myrrha (Nees) Engl., antibacterial, antifungal, anti-inflammatory, antioxidant, antiseptic, antihistamine, di- 
gestive, emmenagogue, stimulates the urinary tract, gingivitis, airways [140-142]; Crocus spp., gastrointestinal disorders, airways, sedative [143-146]; Cucumis melo L., antiinflammatory [147]; Cuminum cynumum L., emmenagogue, gastrointestinal disorders [118]; Curcuma longa L., gastrointestinal disorders, airways [148,149]; Cyclamen hederifolium Aiton, anti-inflammatory [150,151]; Cynoglossum officinale L., analgesic, antibacterial, antihemorrhagic, anti-inflammatory, antiseptic [152]; Cyperus esculentus L., anti-inflammatory [153]; Daucus carota L., circulation [154]; Dorema ammoniacum D. Don, analgesic, antibacterial, anti-inflammatory, antiseptic, antiviral, kidney stones, depurative, dermatitis, diuretic, laxative, neuroprotector, airways [155-158]; Drimia maritima (L.) Stearn, antimicrobial, antioxidant, antitumoral, circulation [159]; Dryopteris filix-mas (L.) Schott, antiinflammatory [160]; Eryngium maritimum L., antioxidant [161]; Eupatorium cannabinum L., anti-inflammatory, choleretic, hepatoprotector [162,163]; Euphorbia spp., laxative, vermifuge/ anthelmintic [164,165]; Ferula gummosa Boiss., antibacterial (E.O. from the seeds), antiinflammatory [166-168]; Foeniculum vulgare Mill., antimicrobial, blood depurative [169]; Fumaria officinalis L., anti-inflammatory, diuretic [170,171]; Galega officinalis L., antibacterial [172]; Glechoma hederacea L., anti-inflammatory [173]; Glycyrrhiza glabra L., antibacterial, anti-inflammatory, antiparasitic, antihistamine, airways [174-176]; Hordeum vulgare L., antidiarrheal, constipation, expectorant (aerial parts, whole fruits) [177,178]; Hypericum perforatum L., antibacterial, anti-inflammatory [179,180]; Larix spp. (or Pinus spp., or Picea spp.), antibacterial, anti-inflammatory, antioxidant, airways [181-183]; Lavandula dentata L. antiinflammatory, antiasthmatic, antioxidant [184]; Lilium candidum L., anti-inflammatory [185]; Linum usitatissimum L., anti-inflammatory [186]; Malus domestica Borkh., antidiarrheal, anti-inflammatory, airways [187-189]; Matricaria chamomilla L., antidiarrheal, spasmolytic, antiulcer, gastrointestinal disorders [79,190]; Melissa officinalis L., spasmolytic [191]; Mentha pulegium L., antimicrobial, circulation [192,193]; Myristica fragrans Houtt., analgesic, antibacterial, anticonvulsant, anti-inflammatory, antioxidant, stomach-ache [194-197]; Myrtus communis L., antioxidant, antiulcer, neuroprotector [198-200]; Narthex asafoetida Falc. ex Lindl., spasmolytic [201,202]; Nigella damscena L., antioxidant, diuretic [203]; Nigella sativa L., anti-inflammatory, antioxidant, diuretic, emmenagogue [203,204]; Olea europaea L., antibacterial (post press waste water), anti-inflammatory [111,205-207]; Origanum majorana L., strengthens the nervous system [208]; Papaver somniferum L., analgesic, antidiarrheal, excitant, neuroprotector, airways [209-213]; Petasites hybridus (L.) G. Gaertn., B. Mey. and Scherb., antiulcer, expectorant [214]; Petroselinum crispum (Mill.) Fuss, antioxidant, diuretic [215]; Pimpinella anisum L., antimicrobial, antioxidant, airways, gastrointestinal disorders [216]; Pimpinella saxifraga L., antibacterial [217]; Piper longum L., anti-inflammatory, antioxidant [218]; Piper nigrum L., anti-inflammatory, antioxidant, antiparasitic, digestive [219-221]; Pistacia lentiscus L., kidney stones (fruit), anti-inflammatory, antioxidant, digestive, hypoglycaemic [222,223]; Pistacia terebinthus L., antioxidant, antimicrobial, antiviral [222]; Polypodium vulgare L., analgesic, antibacterial, antiviral, digestive, laxative, scurvy [224]; Portulaca oleracea L., antihypoxia, anti-inflammatory, antioxidant, hepatoprotector, neuroprotector [225]; Potentilla erecta (L.) Raeusch., antibacterial [226]; Prunus domestica L., antihistamine [227]; Prunus dulcis (Miller) D.A. Webb, anti-inflammatory, emollient (leaves) [228-230]; Prunus persica (L.) Batsch, laxative [231]; Pterocarpus santalinus L.f., antibacterial, anti-inflammatory [232,233]; Pulmonaria officinalis L., antioxidant [234]; Ruscus aculeatus L., spasmolytic (aerial parts) [235]; Rheum officinale L., antiinflammatory, antioxidant, gastrointestinal disorders, airways, thermogenic [236,237]; Rosa spp., antibacterial, anti-inflammatory, laxative, antiviral [238-242]; Rosmarinus officinalis L., antimicrobial, anti-inflammatory [243,244]; Rubia tinctorum L., gastrointestinal disorders [245]; Rubus ulmifolius Schott, anti-inflammatory [246]; Rumex conglomeratus Murray, antibacterial, antioxidant [247,248]; Ruta graveolens L., antibacterial, anti-inflammatory, antipyretic [249,250]; Sambucus ebulus L., antibacterial, anti-inflammatory, antioxidant, diuretic, soothing [251-257]; Sambucus nigra L., diaphoretic, airways viral infections, soothing [251,258-261]; Sanguisorba officinalis L., circulation [262]; Santalum album L., antibacterial, anti-inflammatory [263,264]; Saponaria officinalis L., antiviral [265]; Scorzonera spp., antibac- 
terial, antimicrobial, antifungal, anti-inflammatory, antinematodes, wounds [266-268]; Symphytum officinale L., anti-inflammatory [269]; Tanacetum parthenium (L.) Shc.bip., analgesic, anti-inflammatory, spasmolytic [270,271]; Teucrium scordium L., gastrointestinal disorders [272]; Valeriana spp., gastrointestinal disorders [273]; Thymus spp., anticonvulsant, skin diseases [274,275]; Trigonella foenum-graecum L., anti-inflammatory [276]; Triticum aestivum L., antioxidant, cardio protector (leaves) [277]; Veronica spp., anti-inflammatory [278]; Viola tricolor L., anti-inflammatory [279]; Vitex agnus-castus L., anti-inflammatory [280]; Vitis vinifera L., anti-inflammatory [281]; Zingiber officinale Roscoe, gastric acidity, stomach depurative, stomach-ache, vermifuge/anthelmintic [282-284].

\subsection{Plant Species Checklist for the Restoration of the Ancient Garden of Simples}

The historical and pharmacological bibliographic research based on the inscriptions of the jars allowed listing of the 148 plant taxa that were actively employed at the Ospedale Maggiore Ca' Granda in Milan. If the ancient Pharmacy was indeed the place of manufacture and distribution of the medicinal remedies, it is well-documented that since 1641, the Garden of Simples was the place of cultivation of the plants that made up the remedies themselves [4]. However, to this day, there is very little information concerning the pool of plants hosted in the Garden. The results of the archaeological and palynological analysis performed by Bosi et al. [4] on both plant remains and pollen grains recovered in the area of study, represent a first attempt to resolve this pivotal issue. As a matter of fact, concerning the herbaceous plants, the authors recovered pollen grains belonging to several species of the Apiaceae (probably including Carum carvi L., Pastinaca sativa L., Anethum graveolens L., Aethusa cynapium L., and Pimpinella anisum L. Still) and Compositae families (with Calendula officinalis L., Centaurea benedicta (L.) L., and maybe Centaurea jacea L.). Additionally, further taxa belonging to different families were identified, such as species of the genera Hypericum, Euphorbia, Mercurialis, Mentha, Allium, and Reseda. The remaining pollen residues turned out to be more difficult to interpret, because it could belong to species hosted in the Garden, to plants cultivated nearby, or even weeds. These included Papaver spp., Potentilla spp., Artemisia spp., and Brassica spp. The woody species, on the other hand, presented a more difficult challenge. According to Bosi's team [4], these plants could have been cultivated both for medicinal purposes and as ornamentals. Among these, the following species were identified: evergreen species belonging to the genera Buxus and Juniperus, and fruit-bearing trees such as Morus nigra L., Cydonia oblonga Mill., Juglans regia L., Prunus spp. (perhaps $P$. avium L.), and Vitis spp. (most likely V. vinifera L.). Additional species that were present at the time were Humulus lupulus L., Fraxinus ornus L., Cornus mas L., Olea europaea L., and Castanea sativa L. Nevertheless, according to the authors, it is unreasonable to completely exclude the possibility that these plant remains did not come to be at the Garden from neighbouring areas of Lombardy's territory.

It should also be considered that of the 148 taxa, $76 \%$ are autochthonous, growing spontaneously across Italy. However, Milan's pedoclimatic conditions of the time must also be taken into account. Some species could not have been cultivated in the Garden back in the XVII century due to their thermal requirements, regardless of their presence in the rest of the country. Among these were Cinnamomum camphora (L.) J. Presl, Cinnamomum verum J. Presl, Convolvulus scammonia L., Curcuma longa L., Myristica fragrans Houtt., and Pistacia terebinthus L. On the other hand, other species could have been cultivated in the Garden by taking special precautions, most likely protecting them from cold weather. Examples of these plants are Capparis spinosa L., Drimia maritima (L.) Stern, Glycyrrhiza glabra L., and Myrtus communis L. Conversely, plant species such as Citrus limon L. or Citrus medica L., which prefer more temperate climates, could have been hosted in a sunny and sheltered spot. Another important factor to be considered is the limited area dedicated to cultivation (about $680 \mathrm{~m}^{2}$ ). It is, in fact, improbable that there were a great number of arboreal species, as well as Loranthus europaeus Jacq., which grows as an epiphyte on trees.

An additional consideration arises on the plant part and the drug amounts used in the remedies production. Hypogeal organs were historically requested for some of the 
woody species, such as Capparis spinosa L. and Glycyrrhiza glabra L. Thus, it is reasonable to assume it very unlikely that even a portion of the already limited growing area was dedicated to plants that would have been completely eradicated to obtain the drug. However, these species could be considered excellent additions for the future restored Garden, for display and educational purposes. Some species were seldomly employed in remedies and/or in very limited amounts (i.e., Sanguisorba officinalis L. and Pulmonaria spp.). Others, instead, were used in a variety of recipes (i.e., Artemisia absinthium L. and Ruta graveolens L.). Therefore, it is possible to deduce that the formers were actually grown in the Garden, whereas the latter were most likely supplied from elsewhere. Some historical documents preserved in the Hospital archive were consulted as well (ingredients indexes and supply lists from 1711, 1729, 1760, and 1793 and pharmacopoeias from 1809, 1810-1820, 1819, and 1839 [285-293]). Out of the 148 in our complete list, 85 species were cited in the aforementioned documents, 36 of which were in at least 5 of them. It can be thus hypothesised an actual and continuative use of these plants inside the Hospital during the XVIII and XIX centuries. However, some of the supply lists confirm that several of these species and their derivatives were purchased from outside the Pharmacy; these included Acacia senegal (L.) Willd. (arabic gum), Aloe spp., Cinnamomum camphora (L.) J. Presl, Cinnamomum verum J. Presl, Dorema ammoniacum D. Don (gum ammoniac), Drimia maritima (L.) Stern, Fraxinus ornus L. (manna), Glycyrrhiza glabra L., Papaver somniferum L. (opium), Rheum officinale Baill., Rosa spp. (dried rose petals), and Tamarindus indica L. [288]. Other species, cited in at least 5 of the documents but absent from the supply list, could have been hosted in the Garden; among these are Juniperus communis L., Laurus nobilis L., and Matricaria chamomilla L. Finally, plant-based ingredients such as wine and olive oil were used as a base for most of the remedies produced at the Pharmacy. For this reason, it is more than likely that they too were purchased goods, as opposed to being obtained from the cultivation of Vitis vinifera L. and Olea europaea L. in the Garden. Both these plants would also benefit a potential restored Garden, both as ornamentals and examples of their ancient use. Taking into account all the aforementioned considerations, a list of 40 taxa, belonging to 20 botanical families, was compiled. The most represented families are Lamiaceae (12 species) followed by Compositae and Apiaceae (4 species each), while the most represented genera are Origanum (3) and Mentha (2). The information obtained, along with the 40 species list, represent the basis for the future project of restoration of the ancient Hortus simplicium. The complete list is reported in Table 3.

Table 3. List of species selected for the restoration project of the ancient Hortus simplicium.

\begin{tabular}{c} 
Adoxaceae \\
\hline 1. Sambucus nigra L. \\
Apiaceae \\
\hline 2. Carum carvi L. \\
3. Cuminum cyminum L. \\
4. Pimpinella anisum L. \\
5. Foeniculum vulgare Mill. \\
Boraginaceae \\
6. Borago officinalis L. \\
Compositae \\
7. Achillea millefolium L. \\
8. Centaurea benedicta (L.) L. \\
9. Cichorium intybus L. \\
10. Matricaria chamomilla L. \\
\hline Cucurbitaceae \\
\hline 11. Citrullus colocynthis (L.) Schrad. \\
\hline
\end{tabular}


Table 3. Cont.

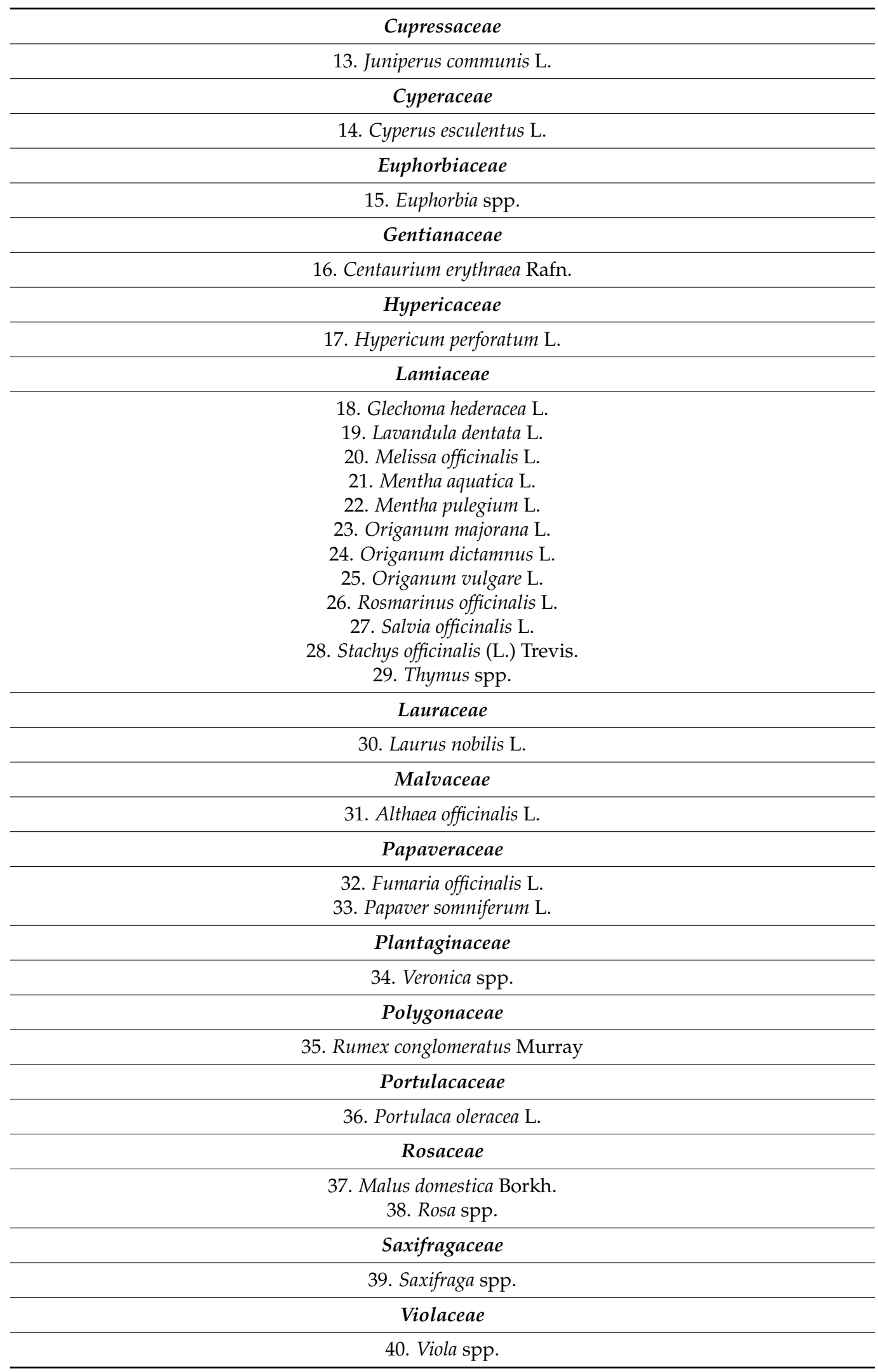




\section{Materials and Methods}

\subsection{Historical Research}

The historical survey led to the identification of the remedies' ingredients once contained in the jars. First, a list of the 150 vases and their inscriptions was drafted. These inscriptions were then analysed and interpreted with the aid of pharmacopoeias, medical texts, and almanacs published between the XV and the XIX centuries [8-20,22-24,26-53,55-62,64-68,70-72,75,77,78,285-293].

Where possible, consultation of writs in vulgar Italian was preferred. The inscriptions were matched directly with the names of the remedies found in the different historical sources. Subsequently, the jars were catalogued according to the origin of either the remedy or the main ingredient. The categories utilised were "plant-based", "mineral", and "animal". All the plant-based ingredients were then tabulated along with the following information: current scientific name (consulting the specialised website http:/ / www. theplantlist.org/, accessed on 30 September 2021), weight, historical medicinal use, and historical source.

\subsection{Pharmacological Research}

Extensive bibliographic research in the pharmacological field was carried out on the plant species obtained during the historical survey phase in order to either validate or refute their ancient medicinal uses. To that end, it was necessary to interpret the historical medical terminology of the pathologies in a modern setting. During this research, several databases were consulted, such as PubMed, Scopus, Google Scholar, and the bibliographic research online tool known as J.A.N.E. A two-step approach was used during the inquiry. Firstly, either the scientific or the common English name of the species was matched with specific keywords related to the categories of pathology that were obtained from historical sources (i.e., Acorus calamus, 'digestive system' or 'gastrointestinal disorders'). Secondly, the plant name was matched with the specific pathology or activity (i.e., Acorus calamus, 'laxative' or 'anti-inflammatory'). The research was primarily focused on systematic reviews and meta-analysis, whenever possible, without applying any year filters. Alternatively, in vitro and in vivo studies, as well as clinical trials, were consulted. The literature inquiry was extended to the mechanism of action, when known. All data were tabulated along with the following information: family, species (scientific and common name), inscription on the vase and inventory number, part of the plant historically used, historical sources, modern use obtained from the historical medicinal use, mechanism of action, and bibliographic references (for complete data, please see Table S1 [8-286,294-297]).

\subsection{Checklist of Potentially Cultivated Species at the Ancient Garden of Simples}

The list of the plant species obtained from the historical research was compared with data from the archaeobotanical study by Bosi et al. [4]. This study was performed on pollen grains recovered at the area of the ancient Garden. This process allowed for the identification of the plant taxa that were potentially present in cultivation at the study area. Each species in the list was then evaluated according to the relative cultivation requirements and the pedoclimatic conditions of the area at the time. Finally, additional considerations were made concerning the part of the plant used in the remedies, the amount in use at the ancient Pharmacy, and XVIII century archived supply ledgers.

\section{Conclusions}

Until the end of the XIX century, official medicine was inextricably linked to the use of plant-based complex remedies. Scientific texts and pharmacopoeias of the time describe elaborate recipes in which animal and mineral ingredients were mixed with plant derivatives in order to produce concoctions that had reportedly almost magical properties. In a time when synthetic drug production was in its infancy and antibiotics did not even exist, in hospitals, doctors administered these peculiar preparations as valid therapies. Ospedale Maggiore Ca' Granda in Milan, along with the annexed Pharmacy and ancient 
Garden of Simples, was for centuries the main venue for these ancient therapeutic practices that could be considered both fascinating and debatable. The multidisciplinary approach of research described herein allowed for the coalescence of results obtained from several complementary fields of study, such as history, pharmacology, archaeology, and agronomy, with the common goal of investigating the plant species used in therapy during the XV-XIX centuries. This was made possible thanks to the accurate analysis of the 150 surviving majolica vases actually preserved in the Pharmacy and once used for the conservation of the ingredients and complex remedies administered to the patients of the Hospital. Through this survey, we could speculate on the pool of species that were once hosted in the ancient Garden of Simples. Finally, the information gleamed in this study will prove to be instrumental in the future restoration project of the Hortus simplicium, in the framework of the historical value and the educational enhancement of a little-known cultural heritage in Milan.

Supplementary Materials: The following are available online. Table S1: Results of the pharmacological survey in scientific literature.

Author Contributions: Conceptualization, G.F.; methodology, G.F. and C.G.; validation, G.F. and C.G.; formal analysis, M.B. and F.M.; investigation, M.B., F.M., P.L.R., L.L. and L.V.; resources, G.F. and C.G.; data curation, M.B. and F.M.; writing-original draft preparation, M.B. and F.M.; writingreview and editing, G.F., C.G., P.M.G., L.M., M.B. and F.M.; visualization, all authors; supervision, G.F.; project administration, G.F. All authors have read and agreed to the published version of the manuscript.

Funding: The authors acknowledge support from the University of Milan through the APC initiative.

Institutional Review Board Statement: Not applicable.

Informed Consent Statement: Not applicable.

Data Availability Statement: Not applicable.

Acknowledgments: Our thanks go to: Fondazione IRCCS Ca' Granda Ospedale Maggiore Policlinico, owner of the vases and the documents object of this research. We are also grateful to Leonardo Molino for revising the English text.

Conflicts of Interest: The authors declare no conflict of interest.

\section{References}

1. Cosmacini, G. La Ca' Granda dei Milanesi: Storia dell'Ospedale Maggiore di Milano; Laterza: Roma/Bari, Italy, 2000.

2. Castelli, G. La Farmacia dell'Ospedale Maggiore nei Secoli; Edizioni Medici Domus: Milano, Italy, 1940.

3. Sironi, V.A. Ospedali e Medicamenti: Storia del Farmacista Ospedaliero; Laterza: Roma/Bari, Italy, 2007.

4. Bosi, G.; Mazzanti, M.B.; Galimberti, P.M.; Mills, J.; Montecchi, M.C.; Rottoli, M.; Torri, P.; Reggio, M. Indagini archeologiche sull'antico giardino dei semplici della Spezieria dell'Ospedale Maggiore di Milano. Archeol. Uomo Territ. 2012, 31, 1-20.

5. Bascapè, G. La "Spezieria" dell'Ospedale Maggiore (sec. XV-XIX). Antichi Ricettari Farmaceutici. La suppellettile artistica: Vasi del Rinascimento e dell'età Barocca, mortai ecc. Le Scuole di Chimica e Farmacia (1783-1860); "Quaderni di Poesia" di Emo Cavalleri: Milano/Como, Italy, 1934.

6. Zanchi, G. La collezione dei vasi da farmacia. In Ospedale Maggiore/Ca' Granda. Collezioni Diverse; Electa: Milano, Italy, 1988; pp. 273-316.

7. Available online: https://www.lombardiabeniculturali.it (accessed on 30 September 2021).

8. Donzelli, G.; Donzelli, T. Teatro Farmaceutico, Dogmatico e Spagirico; Napoli, Italy, 1726. Available online: https://books. google.com.hk/books?hl=zh-CN\&lr=\&id=dVBgAAAAcAAJ\&oi=fnd\&pg=PP11\&dq=Donzelli,+G.\%3B+Donzelli,+T.+Teatro+ Farmaceutico,+Dogmatico+e+Spagirico\&ots=syW7IdzlLr\&sig=Zbvu93VZtRFCQ59mJCJe3dsUI7g\&redir_esc=y\#v=onepage\& q=Donzelli\%2C\%20G.\%3B\%20Donzelli\%2C\%20T.\%20Teatro\%20Farmaceutico\%2C\%20Dogmatico\%20e\%20Spagirico\&f=false (accessed on 30 September 2021).

9. Lémery, N. Farmacopea Universale che Contiene Tutte le Composizioni di Farmacia le quali sono in uso Nella Medicina, tanto in Francia, Quanto per Tutta L'europa, ... e di più un Vocabolario Farmaceutico, Molte Nuove Osservazioni, ed Alcuni Ragionamenti Sopra Ogni op; Gio. Gabriel Hertz: Venezia, Italy, 1720.

10. Castiglione, G.O. Prospectus Pharmaceutici; Mediolani: Caroli Iosephi Quinti: Milano, Italy, 1698.

11. Castiglione, G.O.; Castiglione, B.F.; Galli, C.G. Prospectus Pharmaceutici Editio Tertia, [ ... ]; Caroli Iosephi Quinti: Milano, Italy, 1729. 
12. Collegio dei Medici (Roma); Castelli, P.; Ceccarelli, I. Antidotario romano latino, e volgare. Tradotto da Ippolito Ceccarelli. Li Ragionamenti, e le Aggiunte Dell'elettione de' Semplici, e Prattica delle Compositioni. Con le Annotationi del sig. Pietro Castelli Romano. E Trattati Della Teriaca Romana, e Della; In Venetia per Francesco Brogiollo: Venezia, Italy, 1664.

13. James, R. Dizionario Universale di Medicina di Chirurgia di Chimica di Botanica di Notomia di Farmacia D'istoria Naturale E c. Del Signor James a cui Precede un Discorso Istorico Intorno All'origine e Progressi Della Medicina Tradotto Dall'originale Inglese dai sig; Giambatista Pasquali: Venezia, Italy, 1753.

14. Ettmüller, M. Michaelis Ettmulleri ... Opera Omnia in Quinque tomos Distribuita. Editio Novissima Veneta, Lugdunensi, Francofurtensi et Neapolitana Emendatior, E Locupletior Omnium Completissima cum Integro Textu Schroederi, Morelli, et ludovici; Jo. Gabrielis Hertz: Venezia, Italy, 1734.

15. Royal College of Physicians of London. Pharmacopeia Londinensis: Or, the New London Dispensatory ... Translated into English ... The Seventh Edition, Corrected and Amended. By William Salmon. [With a portrait.]; R. Chiswell: London, UK, 1707.

16. Medicum Collegium Boudewyns. Pharmacia Antuerpiensis Galeno-Chymica. A Medicis Iuratis,ECollegij Medici officialibus ... Edita, etc. [With a Preface by M. Boudewyns.]; Georgium Willemseus: Antwerp, Belgium, 1661.

17. Donzelli, G. Teatro Farmaceutico Dogmatico e Spagirico del Dottore Giuseppe Donzelli ... . Nel Quale S'insegna una Moltiplicità D'arcani Chimici più Sperimentati Dall'autore in Ordine alla Sanità, con Evento non Fallace e con una Canonica Norma di Preparare Ogni Compos; Antonio Bortoli: Venezia, Italy, 1704.

18. Barnaba, G.P.O. Opera di Gio. Pietro Orelli Barnaba di Locarno, ... Nella Quale si Tratta de' Morbi al Corpo Umano Dannosi, con loro Cause, Segni, e Pronostici, con le cure de' Medemi, e con L'aggiunta de' Composti Chimici, ed Altri Particolari Segreti; Carlo Giuseppe Quinto: Milano, Italy, 1711.

19. Culpeper, N. The Complete Herbal; to Which Is Now Added, Upwards of One Hundred Additional Herbs, with a Display of Their Medicinal and Occult Qualities ... to Which Are Now First Annexed, The English Physician, Enlarged, and Key to Physic ... New Edition ... Illustra; Thomas Kelly\&Company: London, UK, 1863.

20. Rossetto, G. I Libri di Gio. Mesue dei Semplici Purgatiui, et Delle Medicine Composte, Adornati di Molti Annotationi, E Dichiarationi Vtilissimi, a li Gioueni, che Vogliono Essercitar L'arte Della Speciaria Come Tesoro di Quella, con Vn'ampia Espositione di Vocabuli; Alessandro de' Vecchi: Venezia, Italy, 1621.

21. Lémery, N. Dizionario overo Trattato Universale delle Droghe Semplici in cui si Ritrovano i loro Differenti nomi, la loro Origine, la loro Scelta, i Principj, che Hanno, le loro Qualità, la loro Etimologia, e Tutto ciò, che v'ha di Particolare Negli Animali, ne' veg; Giuseppe Bertella: Venezia, Italy, 1751.

22. Scoresby-Jackson, R.E. Notebook of Materia Medica, Pharmacology, and Therapeutics; Maclachlan \& Stewart: Edinburgh, UK, 1875.

23. Aldovrandi, U. Antidotarium, à Bonon: Med: Collegio Ampliatum ... Cum dupl. Tab., una Præsidiorum, Altera Morborum; Vittorio Benacci: Bologna, Italy, 1606.

24. Mattioli, P.A. I Discorsi di M. Pietro And. Matthioli Sanese, Medico del Sereniss. Principe Ferdinando Archiduca d'Austria E c. ne i sei libri di Pedacio Dioscoride Anazarbeo Della Materia Medicinale. I Quai Discorsi in Diuersi Luoghi Dall'auttore Medesimo sono Stati ac; Vincenzo Valgrisi: Venezia, Italy, 1559.

25. Aldrovandi, U. ANTIDOTARII BONONIENSIS, siue De Vsitata Ratione Componendorum, Miscendorumq[ue] Medicamontorum, EPITOME; Giovanni Rossi: Bologna, Italy, 1574.

26. Hartmann, P.K. Farmacologia Dinamica per uso Accademico del Dottore in Medicina, ... Fil. car. Hartmann Tradotta dal Latino in Italiano Dalli Fratelli Andrea ed Angelo Buffini con Aggiunte Enunciate Nella loro Prefazione. Dedicata al Chiarissimo Dottore ... Giuseppe Cor; Tipografia Bizzoni: Pavia, Italy, 1827.

27. Donzelli, G. Teatro Farmaceutico Dogmatico, e Spagirico del Dottore Giuseppe Donzelli Napoletano, ... nel Quale S'insegna vna Moltiplicità D'arcani Chimici più Sperimentati Dall'autore, ... Con L'aggiunta in Molti Luoghi del Dottor Tomaso Donzelli Figlio Dell'autore; Felice Cesaretti: Roma, Italy, 1677.

28. Tiling, M. Matthiae Tilingi ... Lilium Curiosum, seu Accurata Lilii albi Descriptio, in qua ejus Natura E Essentia Mirabilis ... Explicantur ... ; Francofurti ad Moenum: Sumptibus Jacobi Gothofredi Seyleri: Typis Balthas. Christoph. Wustii, sen: Frankfurt, Germany, 1683.

29. Maynwaringe, E. Historia et Mysterium luis Venerex: Utrumque Concise Abstractum et Formatum ex Feriis Perpensionibus E Criticis Collationibus Diversarum Repugnantium Opinionum ... Medicorum Anglorum, Gallorum, Hispanorum E Italorum, Dissentientium Scriptorum ( ... ); Nauman \& Wolff: Frankfurt, Germany, 1675.

30. Borgarucci, P. La Fabrica Degli Spetiali Partita in XII Distintioni; Vincenzo Valgrisio: Venezia, Italy, 1566.

31. Geiger, P.L. Pharmacopoea Universalis; Chr. Fr. Winter: Heidelberg, Germany, 1845.

32. Memoirs of the Royal Society, or a New Abridgment of the Philosophical Transactions from 1665 to 1740; J. Nourse: London, UK, 1745.

33. Dresdnisches Magazin oder Ausarbeitungen und Nachrichten zum Behuf der Naturlehre, der Arzneykunst, etc.; Gröll M.: Dresden, Germany, 1760.

34. Elzevier, K. Lexicon Galeno-Chymico-Pharmaceuticum Universale, of Groot-Algemeen Apothekers Woordenboek, Vervattende de Voorschriften der Samengestelde Geneesmiddelen, Die in Alle Bekende Dispensatorien Worden Gevonden ... ; Amsterdam: Amsterdam, The Netherlands, 1790.

35. Manget, J.J. Bibliotheca Medico-Practica ... ; H. Cramer \& Fratrum Philibert: Geneva, Switzerland, 1739.

36. Culpeper, N. Pharmacopcia Londinensis; or, the London Dispensatory, Further Adorned by the Studies and Collections of the Fellows Now Living of the Said College, etc.; Awnsham and John Churchill: London, UK, 1695. 
37. Blanckaert, S. The Physical Dictionary ... The Fifth Edition: With the Addition of Many Thousand Terms of Art ... Also a Catalogue of Characters Used in Physick, Both in Latin and English, Engraved in Copper; Sam Crouch; John Sprint: London, UK, 1708.

38. von Plenck, J.J. Materia Chirurgica, Ovvero Dottrina de' Medicamenti Soliti Usarsi alla cura de' Mali Esterni, del Celebre Profess. G.J. Plenck, Dottore di Chirurgia ... Nella Cesareo Regia Universita di Buda; Giuseppe Orlandelli: Venezia, Italy, 1788.

39. Millar, J. Encyclopaedia Britannica, or a Dictionary of Arts, Sciences, and Miscellaneous Literature; A. Constable and Company: Edimburgh, UK, 1810.

40. Cooley, A.J.; Brough, J.C. Cooley's Cyclopaedia of Practical Receipts, Processes: And Collateral Information in the Arts, Manufactures, Professions, and Trades, Including Medicine, Pharmacy, and Domestic Economy. Designed as a Comprehensive Supplement to the Pharmacopoeias ... ; John Churchill and Son: London, UK, 1864.

41. Graniti, N. Dell'antica, e Moderna Medicina Teorica, e Pratica Meccanicamente Illustrata da Niccolo Graniti patrizio Salernitano Dottor Fisico-Medico-Teologo, Accademico Genial di SICILIA, Della Societa Letteraria di Venezia, Nominato fra gli Arcadi di Roma Filoteo A; Domenico Occhi: Venezia, Italy, 1739.

42. de Gorter, J. Joannis de Gorter ... Chirurgia Repurgata ab Auctore Recensita, Emendata, Multisque in Locis Aucta. Accessit Materies Medica Chirurgiae Repurgatae Accommodata; Giovanni Manfrè: Padova, Italy, 1765.

43. Pereira, J. The Elements of Materia Medica; Longman, Orme, Brown, Green, and Longmans: London, UK, 1840.

44. Wood, G.B.; Bache, F.; Wood, H.C.; Remington, J.P.; Sadtler, S.P.; LaWall, C.H.; Osol, A. The Dispensatory of the United States of America; J. B. Lippincott Company: Philadelphia, PA, USA, 1883.

45. Blanckaert, S. The Physical Dictionary... The Sixth Edition: With the Addition of Many Thousand Terms of Art, and Their Explanation ... Also a Catalogue of the Characters Us'd in Physick, etc.; Sam. Crouch; John\&Benj. Sprint: London, UK, 1715.

46. Beasley, H. The Medical Formulary: Comprising Standard and Approved Formulae for the Preparations and Compounds Employed in Medical Practice; Lindsay \& Blakiston: Philadelphia, PA, USA, 1856.

47. Horst, G. Opera Medica: 3; Johan Andreas and Wolfgang Jun. Haredum: Nuremberg, Germany, 1660.

48. Collegium Medicum Amstelodamensis (Amsterdam). Pharmacopoea Amstelodamensis nova; Petrum Henricum Dronsberg: Amsterdam, The Netherlands, 1792.

49. Dispensatorium Pharmaceuticum Austriaco-Viennense; Collegium Pharmaceuticum Viennense: Wien, Austria, 1751.

50. Dubois, J.; Galenus, C. Mesue et Omnia quae cum eo Imprimi Consueuerunt Pulchrioribus Typis Reformata ... Addita est Iacobi Siluij Interpretatio Canonum Uniuersalium ... Et duo Trochisci Mesue, Quæin Manu Scriptis Exemplaribus Inuenimus: E Quædam Compositiones ex Galeno; Lucantonio Giunti: Venezia, Italy, 1549.

51. Medicorum, C. Antidotarium Bononiense Medic. Collegii Diligenter Emendatum et Auctum ... ; Vittorio Benacci: Bologna, Italy, 1615.

52. The Epitome: A Monthly Retrospect of American Practical Medicine and Surgery; W. A. Townsend: New York, NY, USA, 1886.

53. Garrod, A.B. The Essentials of Materia Medica, and Therapeutics; W. Wood \& Company: New York, NY, USA, 1865.

54. Jourdan, A.J.L.; Sembenini, G.B. Farmacopea Universale Ossia Prospetto Delle Farmacopee Di Amsterdam, Anversa, Dublino, Edimburgo (etc.); Geronimo Tasso: Venezia, Italy, 1833.

55. Blanckaert, S. The Physical Dictionary, Wherein the Terms of Anatomy, the Names and Causes of Diseases, Chirurgical Instruments, and Their Use, Are Accurately Described ... the Seventh Edition, Etc.; John\&Benj. Sprint; Edw. Symon: London, UK, 1726.

56. Zucchi, C.; Ranzoli, A. Prontuario di Farmacia Coll'aggiunta di Nozioni di Chimica Legale e di Chimica Medica; Francesco Vallardi: Milano, Italy, 1855.

57. Beasley, H. The Book of Prescriptions: Containing 2900 Prescriptions Collected from the Practice of the Most Eminent Physicians and Surgeons, English and Foreign; Lindsay \& Blakiston: Philadelphia, PA, USA, 1855.

58. Castelli, P. Antidotario Romano Commentato dal Dottor Pietro Castelli ... Oue S'apporta il Primo Autore di Ciascheduna Compositione, si fa la Collatione con L'altre Ricette, etc. With the Text; G. B. Russo: Cosenza, Italy, 1648.

59. Vossius, G.J. Gerardi Ioannis Vosii de Theologia Gentili, et Physiologia Christiana ... ; Joan Blaeu: Amsterdam, The Netherlands, 1668.

60. Durante, C.; Ferro, G.M. Herbario Nuovo; Giacomo Hertz: Venezia, Italy, 1667.

61. Fantonetti, G. Dizionario dei Termini di Medicina, Chirurgia, Veterinaria, Farmacia, Storia Naturale, Botanica, Fisica, Chimica, ec. di Begin, Boisseau, Jourdain, Montgarny, Richard, Dottori in Medicina, Sanson, Dottore in Chirurgia Dupuy, Professore alla Scuola Veterina; Editori degli Annali Universali delle Scienze e dell'Industria coi tipi di F. e P. Lampato: Milano, Italy, 1828.

62. Cantani, A. Manuale di Farmacologia Clinica (Materia Medica e Terapeutica) Basata Specialmente sui Recenti Progressi Della Fisiologia e Della Clinica: 2; Editori degli Annali Universali delle Scienze e dell'Industria coi tipi di F. e P. Lampato: Milano, Italy, 1887.

63. Direzione Generale della Sanità Pubblica. Farmacopea Ufficiale del Regno D'italia; Tip. Delle Mantellate: Roma, Italy, 1892.

64. Gherardini, G. Supplimento a' Vocabolarj Italiani Proposto da Giovanni Gherardini: L-P. 4; Stamperia di Gius. Bernardoni di Gio: Milano, Italy, 1855.

65. Cassone, F. Flora Medico-Farmaceutica; Tip. di G. Cassone: Torino, Italy, 1850.

66. Casselmann, A. Commentar zur russischen Pharmacopoe, nebst Uebersetzung des Textes, und vergleichender Berücksichtigung der neuesten Pharmacopoeen des Auslandes. ... Bearbeitet von Dr A. Casselmann. Heft 1; St. Pietroburgo, Russia, 1867. Available online: https://play.google.com/store/books/details/Commentar_zur_russischen_Pharmacopoe_nebst_Ueberse?id= GfBZAAAAcAAJ\&hl=bg\&gl=US (accessed on 30 September 2021).

67. Capria, D.M. Dizionario Generale di Chimica, Farmacia, Terapia, Materia-Medica, Tossicologia, Mineralogia e Chimica Applicata alle Arti; Andrea Festa: Napoli, Italy, 1860. 
68. Richter, G.A. Trattato Completo Di Materia Medica. Prima Versione Italiana Del Dottore Domenico Gola; Angelo Bonfanti: Milano, Italy, 1834.

69. Orosi, G. Farmacopea italiana: Pt. 1; Vincenzo Mansi Editore: Livorno, Italy, 1857.

70. Biblioteca Provinciale. Dizionario Delle Scienze Naturali nel quale si Tratta Metodicamente dei Differenti Esseri Della Natura, ... Accompagnato da una Biografia de' piu Celebri Naturalisti, Opera utile ai Medici, agli Agricoltori, ai Mercanti, agli artisti, ai Manifattori, ... ; V. Batelli e Comp.: Firenze, Italy, 1848.

71. Mistichelli, D.; Vincent, H.; Trevisani, F.; De Rossi, A. Trattato Dell'apoplessia in cui con Nuove Osservazioni Anatomiche, e Riflessioni Fisiche si Ricercano Tutte le Cagioni, e Spezie di quel male, e vi si Palesa frà gli altri un Nuovo, E Efficace Rimedio. Dedicato al Reverendiss. Padre, e Padrone Colendiss; Antonio de' Rossi: Roma, Italy, 1709.

72. Chomel, P.G.B. Storia Compendiosa Delle Piante Usuali che Comprende i Diversi Nomi Delle Medesime, la loro Dose, le Principali loro Composizioni in Farmacia, e il Modo di Servirsene di Pier. Gio. Bat. Chomel Tradotta dal Francese ... Tomo Primo-Quinto; Desideri: Roma, Italy, 1809.

73. Soares, F. Pharmacopéa Lusitana Composta pela Commissão Creada por Decreto da Rainha Fidelissima D. Maria II. em 5 de Outubra de 1838. [By F. Soares Franco.]; José Baptista Morando: Lisbon, Portugal, 1841.

74. Hager, H. Pharmacopoea recentiores Anglica, Gallica, Germaniae, Helvetica, Russiae inter se Collatae: Supplementum Manualis Pharmaceutici Hageri; Güntheri: Wrocław, Poland, 1869.

75. Weinberger, R. Compendium der Arzneimittellehre nach der Neuesten Österreichischen Pharmakopoe vom Jahre 1855: Nebst Wortgetreuer Uebersetzung Dieser Pharmakopoe und der neuen Arzneitaxe; Carl Gerold: Wien, Austria, 1855.

76. Càssola, F. Dizionario di Farmacia Generale per Filippo Cassola; Reale Tip. Militare: Napoli, Italy, 1846.

77. Scotti, G. Flora Medica della Provincia di Como; C. Franchi: Como, Italy, 1872.

78. Fedelissimi, G.B. De Febre Maligna Polydaedalae Medicorum Epistolae ad Ioannem Baptistam Fidelissimum ... ; Pietro Antonio Fortunato: Pistoia, Italy, 1628.

79. Miraj, S.; Alesaeidi, S. A systematic review study of therapeutic effects of Matricaria recutita chamomile (chamomile). Electron. Physician 2016, 8, 3024-3031. [CrossRef] [PubMed]

80. Usta, C.; Yildirim, A.B.; Turker, A.U. Antibacterial and antitumour activities of some plants grown in Turkey. Biotechnol. Biotechnol. Equip. 2014, 28, 306-315. [CrossRef] [PubMed]

81. Ali, N.E.; Kaddam, L.A.; Alkarib, S.Y.; Kaballo, B.G.; Khalid, S.A.; Higawee, A.; Abdelhabib, A.; Alaaaldeen, A.; Phillips, A.O.; Saeed, A.M. Gum Arabic (Acacia senegal) Augmented Total Antioxidant Capacity and Reduced C-Reactive Protein among Haemodialysis Patients in Phase II Trial. Int. J. Nephrol. 2020, 2020, 7214673. [CrossRef] [PubMed]

82. Saeidnia, S.; Gohari, A.R.; Mokhber-Dezfuli, N.; Kiuchi, F. A review on phytochemistry and medicinal properties of the genus Achillea. DARU J. Pharm. Sci. 2011, 19, 173-186.

83. Forouzanfar, F.; Hosseinzadeh, H. Medicinal herbs in the treatment of neuropathic pain: A review. Iran. J. Basic Med. Sci. 2018, 21, 347-358. [CrossRef]

84. Ghelani, H.; Chapala, M.; Jadav, P. Diuretic and antiurolithiatic activities of an ethanolic extract of Acorus calamus L. rhizome in experimental animal models. J. Tradit. Complement. Med. 2016, 6, 431-436. [CrossRef] [PubMed]

85. Mukherjee, P.K.; Kumar, V.; Mal, M.; Houghton, P.J. Acorus calamus: Scientific validation of ayurvedic tradition from natural resources. Pharm. Biol. 2007, 45, 651-666. [CrossRef]

86. Rajput, S.B.; Tonge, M.B.; Karuppayil, S.M. An overview on traditional uses and pharmacological profile of Acorus calamus Linn. (Sweet flag) and other Acorus species. Phytomedicine 2014, 21, 268-276. [CrossRef]

87. Al-Snafi, A.E. The chemical constituents and pharmacological effects of Adiantum capillus-veneris-A Review. Int. J. Pharmacol. Toxicol. 2015, 5, 106-111.

88. Dehdari, S.; Hajimehdipoor, H. Medicinal properties of Adiantum capillus-veneris Linn. In traditional medicine and modern phytotherapy: A review article. Iran. J. Public Health 2018, 47, 188-197.

89. Ibraheim, Z.Z.; Ahmed, A.S.; Gouda, Y.G. Phytochemical and biological studies of Adiantum capillus-veneris L. Saudi Pharm. J. 2011, 19, 65-74. [CrossRef]

90. Yuan, Q.; Zang, X.; Liu, Z.; Song, S.; Xue, P.; Wang, J.; Ruan, J. Ethanol extractof Adiantum capillus-veneris L. suppresses the production of inflammatory mediators by inhibiting NF-kB activation. J. Ethnopharmacol. 2013, 147, 603-611. [CrossRef]

91. Agrawal, D.C.; Dhanasekaran, M. Medicinal Mushrooms: Recent Progress in Research and Development; Springer: New York, NY, USA, 2019; ISBN 9811363811.

92. Wu, F.; Zhou, L.W.; Yang, Z.L.; Bau, T.; Li, T.H.; Dai, Y.C. Resource Diversity of Chinese Macrofungi: Edible, Medicinal and Poisonous Species; Springer: Dordrecht, The Netherlands, 2019; Volume 98, ISBN 0123456789.

93. Santos, T.N.; Costa, G.; Ferreira, J.P.; Liberal, J.; Francisco, V.; Paranhos, A.; Cruz, M.T.; Castelo-Branco, M.; Figueiredo, I.V.; Batista, M.T. Antioxidant, Anti-Inflammatory, and Analgesic Activities of Agrimonia eupatoria L. Infusion. Evid.-Based Complement. Altern. Med. 2017, 2017, 8309894. [CrossRef]

94. Bastian, P.; Fal, A.M.; Jambor, J.; Michalak, A.; Noster, B.; Sievers, H.; Steuber, A.; Walas-Marcinek, N. Candelabra Aloe (Aloe arborescens) in the therapy and prophylaxis of upper respiratory tract infections: Traditional use and recent research results. Wien. Med. Wochenschr. 2013, 163, 73-79. [CrossRef] [PubMed]

95. Hekmatpou, D.; Mehrabi, F.; Rahzani, K.; Aminiyan, A. The effect of Aloe vera clinical trials on prevention and healing of skin wound: A systematic review. Iran. J. Med. Sci. 2019, 44, 1-9. [PubMed] 
96. Jain, S.; Rathod, N.; Nagi, R.; Sur, J.; Laheji, A.; Gupta, N.; Agrawal, P.; Prasad, S. Antibacterial effect of Aloe vera gel against oral pathogens: An in-vitro study. J. Clin. Diagn. Res. 2016, 10, ZC41-ZC44. [CrossRef]

97. Mwale, M.; Masika, P.J. In vivo anthelmintic efficacy of Aloe ferox, Agave sisalana, and Gunnera perpensa in village chickens naturally infected with Heterakis gallinarum. Trop. Anim. Health Prod. 2015, 47, 131-138. [CrossRef]

98. Zheng, Y.F.; Liu, C.F.; Lai, W.F.; Xiang, Q.; Li, Z.F.; Wang, H.; Lin, N. The laxative effect of emodin is attributable to increased aquaporin 3 expression in the colon of mice and HT-29 cells. Fitoterapia 2014, 96, 25-32. [CrossRef] [PubMed]

99. Bonaterra, G.A.; Bronischewski, K.; Hunold, P.; Schwarzbach, H.; Heinrich, E.U.; Fink, C.; Aziz-Kalbhenn, H.; Müller, J.; Kinscherf, R. Anti-inflammatory and Anti-oxidative Effects of Phytohustil ${ }^{\circledR}$ and Root Extract of Althaea officinalis L. on Macrophages in vitro. Front. Pharmacol. 2020, 11, 290. [CrossRef] [PubMed]

100. Mahboubi, M. Marsh Mallow (Althaea officinalis L.) and Its Potency in the Treatment of Cough. Complement. Med. Res. 2020, 27, 174-183. [CrossRef]

101. Paun, G.; Neagu, E.; Albu, C.; Savin, S.; Radu, G.L. In Vitro Evaluation of Antidiabetic and Anti-Inflammatory Activities of Polyphenolic-Rich Extracts from Anchusa officinalis and Melilotus officinalis. ACS Omega 2020, 5, 13014-13022. [CrossRef]

102. Al-Snafi, A.E. The pharmacological importance of Anethum graveolens. A review. Int. J. Pharm. Pharm. Sci. 2014, 6, 11-13.

103. Sowndhararajan, K.; Deepa, P.; Kim, M.; Park, S.J.; Kim, S. A review of the composition of the essential oils and biological activities of Angelica species. Sci. Pharm. 2017, 85, 33. [CrossRef]

104. Batiha, G.E.; Olatunde, A.; El-mleeh, A.; Hetta, H.F.; Al-rejaie, S.; Alghamdi, S.; Zahoor, M.; Beshbishy, A.M. Pharmacokinetics of Wormwood (Artemisia absinthium). Antibiotics 2020, 9, 353. [CrossRef] [PubMed]

105. Ali, S.; Ejaz, M.; Dar, K.K.; Nasreen, S.; Ashraf, N.; Gillani, S.F.; Shafi, N.; Safeer, S.; Khan, M.A.; Andleeb, S.; et al. Evaluation of chemopreventive and chemotherapeutic effect of Artemisia vulgaris extract against diethylnitrosamine induced hepatocellular carcinogenesis in balb c mice. Braz. J. Biol. 2020, 80, 484-496. [CrossRef]

106. Saeedi, M.; Vahedi-Mazdabadi, Y.; Rastegari, A.; Soleimani, M.; Eftekhari, M.; Akbarzadeh, T.; Khanavi, M. Evaluation of Asarum europaeum L. Rhizome for the Biological Activities Related to Alzheimer's Disease. Res. J. Pharmacogn. 2020, 7, 25-33. [CrossRef]

107. Iqbal, M.; Bibi, Y.; Iqbal Raja, N.; Ejaz, M.; Hussain, M.; Yasmeen, F.; Saira, H.; Imran, M. Review on Therapeutic and Pharmaceutically Important Medicinal Plant Asparagus officinalis L. J. Plant Biochem. Physiol. 2017, 5, 2. [CrossRef]

108. Sohn, Y.M.; Chin, Y.W.; Yang, M.H.; Kim, J. Terpenoid constituents from the aerial parts of Asplenium scolopendrium. Nat. Prod. Sci. 2008, 14, 265-268.

109. Tomić, A.; Petrović, S.; Tzakou, O.; Couladis, M.; Milenković, M.; Vučićević, D.; Lakušić, B. Composition and antimicrobial activity of the rhizome essential oils of two Athamanta turbith subspecies. J. Essent. Oil Res. 2009, 21, 276-279. [CrossRef]

110. Asadi-Samani, M.; Bahmani, M.; Rafieian-Kopaei, M. The chemical composition, botanical characteristic and biological activities of Borago officinalis: A review. Asian Pac. J. Trop. Med. 2014, 7, S22-S28. [CrossRef]

111. Ghasemian, M.; Owlia, S.; Owlia, M.B. Review of Anti-Inflammatory Herbal Medicines. Adv. Pharmacol. Sci. 2016, $2016,9130979$. [CrossRef] [PubMed]

112. Gilani, A.H.; Bashir, S.; Khan, A. ullah Pharmacological basis for the use of Borago officinalis in gastrointestinal, respiratory and cardiovascular disorders. J. Ethnopharmacol. 2007, 114, 393-399. [CrossRef] [PubMed]

113. Mirsadraee, M.; Moghaddam, S.K.; Saeedi, P.; Ghaffari, S. Effect of Borago officinalis extract on moderate persistent asthma: A phase two randomized, double blind, placebo-controlled clinical trial. Tanaffos 2016, 15, 168-174. [CrossRef] [PubMed]

114. Al-Yasiry, A.R.M.; Kiczorowska, B. Frankincense-Therapeutic properties. Postepy Hig. Med. Dosw. 2016, 70, 380-391. [CrossRef] [PubMed]

115. Abdel-Tawab, M.; Werz, O.; Schubert-Zsilavecz, M. Boswellia serrata. Altern. Med. Rev. 2008, 13, 165-167. [CrossRef]

116. Siddiqui, M.Z. Boswellia serrata, a potential antiinflammatory agent: An overview. Indian J. Pharm. Sci. 2011, 73, $255-261$. [CrossRef]

117. Ukiya, M.; Akihisa, T.; Yasukawa, K.; Tokuda, H.; Toriumi, M.; Koike, K.; Kimura, Y.; Nikaido, T.; Aoi, W.; Nishino, H.; et al. Anti-inflammatory and anti-tumor-promoting effects of cucurbitane glycosides from the roots of Bryonia dioica. J. Nat. Prod. 2002, 65, 179-183. [CrossRef]

118. Johri, R.K. Cuminum cyminum and Carum carvi: An update. Pharmacogn. Rev. 2011, 5, 63-72. [CrossRef]

119. Mahboubi, M. Caraway as Important Medicinal Plants in Management of Diseases. Nat. Prod. Bioprospect. 2019, 9, 1-11. [CrossRef]

120. Eddouks, M.; Lemhadri, A.; Michel, J.B. Hypolipidemic activity of aqueous extract of Capparis spinosa L. in normal and diabetic rats. J. Ethnopharmacol. 2005, 98, 345-350. [CrossRef]

121. Gadgoli, C.; Mishra, S.H. Antihepatotoxic activity of p-methoxy benzoic acid from Capparis spinosa. J. Ethnopharmacol. 1999, 66, 187-192. [CrossRef]

122. Zhang, H.; Ma, Z.F. Phytochemical and pharmacological properties of Capparis spinosa as a medicinal plant. Nutrients 2018, 10, 116. [CrossRef] [PubMed]

123. Berkan, T.; Ustunes, L.; Lermioglu, F.; Ozer, A. Antiinflammatory, analgesic, and antipyretic effects of an aqueous extract of Erythraea centaurium. Planta Med. 1991, 57, 34-37. [CrossRef]

124. Mroueh, M.; Saab, Y.; Rizkallah, R. Hepatoprotective activity of Centaurium erythraea on acetaminophen-induced hepatotoxicity in rats. Phyther. Res. 2004, 18, 431-433. [CrossRef] [PubMed] 
125. Mabona, U. Antimicrobial activity of southern African medicinal plants with dermatological relevance Unathi Mabona. J. Ethnopharmacol. 2013, 148, 45-55. [CrossRef]

126. Queiroz, L.S.; Ferreira, E.A.; Mengarda, A.C.; Almeida, A.d.C.; Pinto, P.d.F.; Coimbra, E.S.; de Moraes, J.; Denadai, Â.M.L.; Da Silva Filho, A.A. In vitro and in vivo evaluation of cnicin from blessed thistle (Centaurea benedicta) and its inclusion complexes with cyclodextrins against Schistosoma mansoni. Parasitol. Res. 2020, 120, 1321-1333. [CrossRef] [PubMed]

127. Durdević, L.; Mitrović, M.; Pavlović, P.; Bojović, S.; Jarić, S.; Oberan, L.; Gajić, G.; Kostić, O. Total phenolics and phenolic acids content in leaves, rhizomes and rhizosphere soil under Ceterach officinarum D.C., Asplenium trichomanes L. and A. adiantum nigrum L. in the Gorge of Sićevo (Serbia). Ekol. Bratisl. 2007, 26, 164-173.

128. Zangeneh, M.M.; Zangeneh, A.; Bahrami, E.; Almasi, M.; Amiri-Paryan, A.; Tahvilian, R.; Moradi, R. Evaluation of hematoprotective and hepatoprotective properties of aqueous extract of Ceterach officinarum DC against streptozotocin-induced hepatic injury in male mice. Comp. Clin. Pathol. 2018, 27, 1427-1436. [CrossRef]

129. Chen, C.J.; Deng, A.J.; Liu, C.; Shi, R.; Qin, H.L.; Wang, A.P. Hepatoprotective activity of Cichorium endivia L. extract and its chemical constituents. Molecules 2011, 16, 9049-9066. [CrossRef]

130. Warashina, T.; Miyase, T. Sesquiterpenes from the Roots of Cichorium endivia. Chem. Pharm. Bull. 2008, 56, 1445-1451. [CrossRef]

131. Li, Z.H.; Cai, M.; Liu, Y.S.; Sun, P.L.; Luo, S.L. Antibacterial Activity and Mechanisms of Essential Oil from Citrus medica L. var. Sarcodactylis. Molecules 2019, 24, 1577. [CrossRef]

132. Mahilrajan, S.; Nandakumar, J.; Kailayalingam, R.; Manoharan, N.A.; SriVijeindran, S.T. Screening the antifungal activity of essential oils against decay fungi from palmyrah leaf handicrafts. Biol. Res. 2014, 47, 35. [CrossRef]

133. Xiao, S.; Yu, H.; Xie, Y.; Guo, Y.; Fan, J.; Yao, W. The anti-inflammatory potential of Cinnamomum camphora (L.) J.Presl essential oil in vitro and in vivo. J. Ethnopharmacol. 2021, 267, 113516. [CrossRef] [PubMed]

134. Xu, Y.; Qin, J.; Wang, P.; Li, Q.; Yu, S.; Zhang, Y.; Wang, Y. Chemical composition and larvicidal activities of essential oil of Cinnamomum camphora (L.) leaf against anopheles stephensi. Rev. Soc. Bras. Med. Trop. 2020, 53, e20190211. [CrossRef] [PubMed]

135. Csikós, E.; Cseko, K.; Ashraf, A.R.; Kemény, Á.; Kereskai, L.; Kocsis, B.; Böszörményi, A.; Helyes, Z.; Horváth, G. Effects of Thymus vulgaris L., Cinnamomum verum J.Presl and Cymbopogon nardus (L.) rendle essential oils in the endotoxin-induced acute airway inflammation mouse model. Molecules 2020, 25, 3553. [CrossRef]

136. Ling, L.; Jiang, Y.; Liu, Y.; Li, H.; Bari, A.; Ullah, R.; Xue, J. Role of gold nanoparticle from Cinnamomum verum against 1methyl-4-phenyl-1, 2, 3, 6-tetrahydropyridine (MPTP) induced mice model. J. Photochem. Photobiol. B Biol. 2019, $201,111657$. [CrossRef]

137. Williams, A.R.; Ramsay, A.; Hansen, T.V.A.; Ropiak, H.M.; Mejer, H.; Nejsum, P.; Mueller-Harvey, I.; Thamsborg, S.M. Anthelmintic activity of trans-cinnamaldehyde and A-and B-type proanthocyanidins derived from cinnamon (Cinnamomum verum). Sci. Rep. 2015, 5, 14791. [CrossRef]

138. Pashmforosh, M.; Vardanjani, H.R.; Vardanjani, H.R.; Pashmforosh, M.; Khodayar, M.J. Topical anti-inflammatory and analgesic activities of Citrullus colocynthis extract cream in rats. Medicina 2018, 54, 51. [CrossRef] [PubMed]

139. Al-sieni, A.I.I. The antibacterial activity of traditionally used Salvadora persica L. (miswak) and Commiphora gileadensis (palsam) in Saudi Arabia. Afr. J. Tradit. Complement. Altern. Med. 2014, 11, 23-27. [CrossRef]

140. El Ashry, E.S.H.; Rashed, N.; Salama, O.M.; Saleh, A. Components, therapeutic value and uses of myrrh. Pharmazie 2003, 58, 163-168.

141. Shin, J.; Che, D.; Cho, B.; Kang, H.; Kim, J.; Jang, S. Commiphora myrrha inhibits itch-associated histamine and IL-31 production in stimulated mast cells. Exp. Ther. Med. 2019, 1914-1920. [CrossRef] [PubMed]

142. Sotoudeh, R.; Hadjzadeh, M.-A.-R.; Gholamnezhad, Z.; Aghaei, A. The anti-diabetic and antioxidant effects of a combination of Commiphora mukul, Commiphora myrrha and Terminalia chebula in diabetic rats. Avicenna J. Phytomed. 2019, 9, 454-464. [CrossRef] [PubMed]

143. Khorasany, A.R.; Hosseinzadeh, H. Therapeutic effects of saffron (Crocus sativus L.) in digestive disorders: A review. Iran. J. Basic Med. Sci. 2016, 19, 455-469. [CrossRef]

144. Kianmehr, M.; Khazdair, M.R. Possible therapeutic effects of Crocus sativus stigma and its petal flavonoid, kaempferol, on respiratory disorders. Pharm. Biol. 2020, 58, 1140-1149. [CrossRef]

145. Liu, Z.; Chen, Y.; Zhang, H.; Hua, L.J. Crocus sativus L. protects against SDS-induced intestinal damage and extends lifespan in Drosophila melanogaster. Mol. Med. Rep. 2016, 14, 5601-5606. [CrossRef] [PubMed]

146. Umigai, N.; Takeda, R.; Mori, A. Effect of crocetin on quality of sleep: A randomized, double-blind, placebo-controlled, crossover study. Complement. Ther. Med. 2018, 41, 47-51. [CrossRef]

147. Ezzat, S.M.; Raslan, M.; Salama, M.M.; Menze, E.T.; El Hawary, S.S. In vivo anti-inflammatory activity and UPLC-MS/MS profiling of the peels and pulps of Cucumis melo var. cantalupensis and Cucumis melo var. reticulatus. J. Ethnopharmacol. 2019, 237, 245-254. [CrossRef]

148. Lelli, D.; Sahebkar, A.; Johnston, T.P.; Pedone, C. Curcumin use in pulmonary diseases: State of the art and future perspectives. Pharmacol. Res. 2017, 115, 133-148. [CrossRef]

149. Salehi, B.; Stojanović-Radić, Z.; Matejić, J.; Sharifi-Rad, M.; Anil Kumar, N.V.; Martins, N.; Sharifi-Rad, J. The therapeutic potential of curcumin: A review of clinical trials. Eur. J. Med. Chem. 2018, 163, 527-545. [CrossRef]

150. Mansour, O.; Salamma, R.; Abbas, L. Screening of antibacterial activity in vitro of Cyclamen hederifolium tubers extracts. Res. J. Pharm. Technol. 2016, 9, 1837-1839. [CrossRef] 
151. Mohammed, G.J.; Hameed, I.H.; Kamal, S.A. Anti-inflammatory effects and other uses of Cyclamen species: A review. Indian J. Public Health Res. Dev. 2018, 9, 206-211. [CrossRef]

152. Segneanu, A.-E.; Cepan, C.; Grozescu, I.; Cziple, F.; Olariu, S.; Ratiu, S.; Lazar, V.; Marius Murariu, S.; Maria Velciov, S.; Daniela Marti, T. Therapeutic Use of Some Romanian Medicinal Plants. Pharmacogn.-Med. Plants 2019. [CrossRef]

153. Udefa, A.L.; Amama, E.A.; Archibong, E.A.; Nwangwa, J.N.; Adama, S.; Inyang, V.U.; Inyaka, G.U.-u.; Aju, G.J.; Okpa, S.; Inah, I.O. Antioxidant, anti-inflammatory and anti-apoptotic effects of hydro-ethanolic extract of Cyperus esculentus L. (tigernut) on lead acetate-induced testicular dysfunction in Wistar rats. Biomed. Pharmacother. 2020, 129, 110491. [CrossRef]

154. Ahmad, T.; Cawood, M.; Iqbal, Q.; Ariño, A.; Batool, A.; Sabir Tariq, R.M.; Azam, M.; Akhtar, S. Phytochemicals in Daucus carota and their health benefits-review article. Foods 2019, 8, 424. [CrossRef]

155. Kumar, V.P.; Chauhan, N.S.; Padh, H.; Rajani, M. Search for antibacterial and antifungal agents from selected Indian medicinal plants. J. Ethnopharmacol. 2006, 107, 182-188. [CrossRef]

156. Mobeen, A.; Siddiqui, M.A.; Khan, I.; Quamri, M.A.; Itrat, M.; Khan, M.I. Therapeutic potential of Ushaq (Dorema ammoniacum D. Don): A unique drug of Unani medicine. Int. J. Unani Integr. Med. 2018, 2, 11-16.

157. Mottaghipisheh, J.; Vitalini, S.; Pezzani, R.; Iriti, M. A comprehensive Review on Ethnobotanical, Phytochemical and Pharmacological Aspects of the Genus Dorema; Springer: Dordrecht, The Netherlands, 2021; ISBN 0123456789.

158. Rajani, M.; Saxena, N.; Ravishankara, M.N.; Desai, N.; Padh, H. Evaluation of the antimicrobial activity of ammoniacum gum from Dorema ammoniacum. Pharm. Biol. 2002, 40, 534-541. [CrossRef]

159. Bozorgi, M.; Amin, G.; Shekarchi, M.; Rahimi, R. Traditional medical uses of Drimia species in terms of phytochemistry, pharmacology and toxicology. J. Tradit. Chin. Med. 2017, 37, 124-139. [CrossRef]

160. Erhirhie, E.O.; Emeghebo, C.N.; Ilodigwe, E.E.; Ajaghaku, D.L.; Umeokoli, B.O.; Eze, P.M.; Ngwoke, K.G.; Chiedu Okoye, F.B.G. Dryopteris filix-mas (L.) Schott ethanolic leaf extract and fractions exhibited profound anti-inflammatory activity. Avicenna J. Phytomed. 2019, 9, 396-409. [CrossRef]

161. Meot-Duros, L.; Le Floch, G.; Magné, C. Radical scavenging, antioxidant and antimicrobial activities of halophytic species. J. Ethnopharmacol. 2008, 116, 258-262. [CrossRef] [PubMed]

162. Chen, J.J.; Tsai, Y.C.; Hwang, T.L.; Wang, T.C. Thymol, benzofuranoid, and phenylpropanoid derivatives: Anti-inflammatory constituents from Eupatorium cannabinum. J. Nat. Prod. 2011, 74, 1021-1027. [CrossRef]

163. Lexa, A.; Fleurentin, J.; Lehr, P.R.; Mortier, F.; Pruvost, M.; Pelt, J.M. Choleretic and hepatoprotective properties of Eupatorium cannabinum in the rat. Planta Med. 1989, 55, 127-132. [CrossRef]

164. Lone, B.A.; Bandh, S.A.; Chishti, M.Z.; Bhat, F.A.; Tak, H.; Nisa, H. Anthelmintic and antimicrobial activity of methanolic and aqueous extracts of Euphorbia helioscopia L. Trop. Anim. Health Prod. 2013, 45, 743-749. [CrossRef] [PubMed]

165. Wang, K.; Liu, L.; Huang, J.; Yu, H.; Wu, H.; Duan, Y.; Cui, X.; Zhang, X.; Liu, L.; Wang, W. Laxative effects of total diterpenoids extracted from the roots of euphorbia pekinensis are attributable to alterations of aquaporins in the colon. Molecules 2017, 22, 465. [CrossRef] [PubMed]

166. Farid-Afshar, F.; Saffarian, P.; Mahmoodzadeh-Hosseini, H.; Sattarian, F.; Amin, M.; Fooladi, A.A.I. Antimicrobial effects of Ferula gummosa boiss gum against extended-spectrum $\beta$-lactamase producing Acinetobacter clinical isolates. Iran. J. Microbiol. 2016, 8 , 263-273.

167. Masoumi-Ardakani, Y.; Mandegary, A.; Esmaeilpour, K.; Najafipour, H.; Sharififar, F.; Pakravanan, M.; Ghazvini, H. Chemical composition, anticonvulsant activity, and toxicity of essential oil and methanolic extract of Elettaria cardamomum. Planta Med. 2016, 82, 1482-1486. [CrossRef]

168. Nazemisalman, B.; Vahabi, S.; Yazdinejad, A.; Haghghi, F.; Jam, M.; Heydari, F. Comparison of antimicrobial effect of Ziziphora tenuior, Dracocephalum moldavica, Ferula gummosa, and Prangos ferulacea essential oil with chlorhexidine on Enterococcus faecalis: An in vitro study. Dent. Res. J. (Isfahan) 2018, 15, 111-116. [CrossRef]

169. Badgujar, S.B.; Patel, V.V.; Bandivdekar, A.H. Foeniculum vulgare Mill: A Review of Its Botany, Phytochemistry, Pharmacology, Contemporary Application, and Toxicology. Biomed Res. Int. 2014, 2014, 842674. [CrossRef]

170. Pǎltinean, R.; Mocan, A.; Vlase, L.; Gheldiu, A.M.; Crişan, G.; Ielciu, I.; Voştinaru, O.; Crişan, O. Evaluation of polyphenolic content, antioxidant and diuretic activities of six Fumaria species. Molecules 2017, 22, 639. [CrossRef]

171. Raafat, K.M.; El-Zahaby, S.A. Niosomes of active Fumaria officinalis phytochemicals: Antidiabetic, antineuropathic, antiinflammatory, and possible mechanisms of action. Chin. Med. (UK) 2020, 15, 40. [CrossRef] [PubMed]

172. Pundarikakshudu, K.; Patel, J.K.; Bodar, M.S.; Deans, S.G. Anti-bacterial activity of Galega officinalis L. (Goat's Rue). J. Ethnopharmacol. 2001, 77, 111-112. [CrossRef]

173. Chou, S.T.; Lin, T.H.; Peng, H.Y.; Chao, W.W. Phytochemical profile of hot water extract of Glechoma hederacea and its antioxidant, and anti-inflammatory activities. Life Sci. 2019, 231, 116519. [CrossRef] [PubMed]

174. Batiha, G.E.S.; Beshbishy, A.M.; El-Mleeh, A.; Abdel-Daim, M.M.; Devkota, H.P. Traditional uses, bioactive chemical constituents, and pharmacological and toxicological activities of Glycyrrhiza glabra L. (fabaceae). Biomolecules 2020, 10, 352. [CrossRef] [PubMed]

175. Han, S.; Sun, L.; He, F.; Che, H. Anti-Allergic activity of glycyrrhizic acid on IgE-mediated allergic reaction by regulation of allergy-related immune cells. Sci. Rep. 2017, 7, 7222. [CrossRef]

176. Zhang, D.; Liu, B.; Cao, B.; Wei, F.; Yu, X.; Li, G.-f.; Chen, H.; Wei, L.-q.; Wang, P. Lan Synergistic protection of Schizandrin B and Glycyrrhizic acid against bleomycin-induced pulmonary fibrosis by inhibiting TGF- $\beta 1 / \mathrm{Smad} 2$ pathways and overexpression of NOX4. Int. Immunopharmacol. 2017, 48, 67-75. [CrossRef] 
177. Xia, X.; Li, G.; Ding, Y.; Ren, T.; Zheng, J.; Kan, J. Effect of Whole Grain Qingke (Tibetan Hordeum vulgare L. Zangqing 320) on the Serum Lipid Levels and Intestinal Microbiota of Rats under High-Fat Diet. J. Agric. Food Chem. 2017, 65, 2686-2693. [CrossRef]

178. Zeng, Y.; Pu, X.; Yang, J.; Du, J.; Yang, X.; Li, X.; Li, L.; Zhou, Y.; Yang, T. Preventive and therapeutic role of functional ingredients of barley grass for chronic diseases in human beings. Oxid. Med. Cell. Longev. 2018, 2018, 3232080. [CrossRef]

179. Hammer, K.D.P.; Birt, D.F. Evidence for Contributions of Interactions of Constituents to the Anti-Inflammatory Activity of Hypericum Perforatum. Crit. Rev. Food Sci. Nutr. 2014, 54, 781-789. [CrossRef]

180. Saddiqe, Z.; Naeem, I.; Maimoona, A. A review of the antibacterial activity of Hypericum perforatum L. J. Ethnopharmacol. 2010, 131, 511-521. [CrossRef]

181. Mercier, B.; Prost, J.; Prost, M. The essential oil of turpentine and its major volatile fraction ( $\alpha$ - and $\beta$-pinenes): A review. Int. J. Occup. Med. Environ. Health 2009, 22, 331-342. [CrossRef] [PubMed]

182. Schelz, Z.; Molnar, J.; Hohmann, J. Antimicrobial and antiplasmid activities of essential oils. Fitoterapia 2006, 77, $279-285$. [CrossRef] [PubMed]

183. Sipponen, A.; Laitinen, K. Antimicrobial properties of natural coniferous rosin in the European Pharmacopoeia challenge test. Apmis 2011, 119, 720-724. [CrossRef]

184. Almohawes, Z.N.; Alruhaimi, H.S. Effect of Lavandula dentata extract on ovalbumin-induced asthma in male Guinea pigs. Braz. J. Biol. 2020, 80, 87-96. [CrossRef] [PubMed]

185. Zaccai, M.; Yarmolinsky, L.; Khalfin, B.; Budovsky, A.; Gorelick, J.; Dahan, A.; Ben-Shabat, S. Medicinal properties of Lilium candidum L. and its phytochemicals. Plants 2020, 9, 959. [CrossRef]

186. Rafieian-kopaei, M.; Shakiba, A.; Sedighi, M.; Bahmani, M. The Analgesic and Anti-Inflammatory Activity of Linum usitatissimum in Balb/c Mice. J. Evid.-Based Complement. Altern. Med. 2017, 22, 892-896. [CrossRef]

187. Patocka, J.; Bhardwaj, K.; Klimova, B.; Nepovimova, E.; Wu, Q.; Landi, M.; Kuca, K.; Valis, M.; Wu, W. Malus domestica: A review on nutritional features, chemical composition, traditional and medicinal value. Plants 2020, 9, 1408. [CrossRef]

188. Saito, T.; Miyake, M.; Toba, M.; Okamatsu, H.; Shimizu, S.; Noda, M. Inhibition by apple polyphenols of ADP-ribosyltransferase activity of cholera toxin and toxin-induced fluid accumulation in mice. Microbiol. Immunol. 2002, 46, 249-255. [CrossRef]

189. Woods, R.K.; Walters, E.H.; Raven, J.M.; Wolfe, R.; Ireland, P.D.; Thien, F.C.K.; Abramson, M.J. Food and nutrient intakes and asthma risk in young adults. Am. J. Clin. Nutr. 2003, 78, 414-421. [CrossRef]

190. Singh, O.; Khanam, Z.; Misra, N.; Srivastava, M.K. Chamomile (Matricaria chamomilla). An overview. Pharm. Rev. 2011, 5, 82-95. [CrossRef]

191. Aubert, P.; Guinobert, I.; Blondeau, C.; Bardot, V.; Ripoche, I.; Chalard, P.; Neunlist, M. Basal and spasmolytic effects of a hydroethanolic leaf extract of Melissa officinalis L. on intestinal motility: An ex vivo study. J. Med. Food 2019, 22, 653-662. [CrossRef] [PubMed]

192. Azhar, A.S.; El-Bassossy, H.M.; Abdallah, H.M. Mentha longifolia alleviates experimentally induced angina via decreasing cardiac load. J. Food Biochem. 2019, 43, e12702. [CrossRef] [PubMed]

193. Rad, S.S.; Sani, A.M.; Mohseni, S. Biosynthesis, characterization and antimicrobial activities of zinc oxide nanoparticles from leaf extract of Mentha pulegium (L.). Microb. Pathog. 2019, 131, 239-245. [CrossRef]

194. Asgarpanah, J.; Kazemivash, N. Phytochemistry and pharmacologic properties of Myristica fragrans Hoyutt: A review. Afr. J. Biotechnol. 2012, 11, 12787-12793. [CrossRef]

195. Gupta, A.D.; Bansal, V.K.; Babu, V.; Maithil, N. Chemistry, antioxidant and antimicrobial potential of nutmeg (Myristica fragrans Houtt). J. Genet. Eng. Biotechnol. 2013, 11, 25-31. [CrossRef]

196. Jaiswal, P.; Kumar, P.; Singh, V.K.; Singh, D.K. ARBS Annual Review of Biomedical Sciences Biological Effects of Myristica fragrans. ARBS Annu. Rev. Biomed. Sci. 2009, 11, 21-29.

197. Olajide, O.A.; Ajayi, F.F.; Ekhelar, A.I.; Awe, S.O.; Makinde, J.M.; Alada, A.R.A. Biological effects of Myristica fragrans (nutmeg) extract. Phyther. Res. 1999, 13, 344-345. [CrossRef]

198. Alipour, G.; Dashti, S.; Hosseinzadeh, H. Review of pharmacological effects of Myrtus communis L. and its active constituents. Phyther. Res. 2014, 28, 1125-1136. [CrossRef]

199. Hennia, A.; Miguel, M.; Nemmiche, S. Antioxidant Activity of Myrtus communis L. and Myrtus nivellei Batt. \& Trab. Extracts: A Brief Review. Medicines 2018, 5, 89. [CrossRef]

200. Sumbul, S.; Aftab Ahmad, M.; Asif, M.; Akhtar, M. Myrtus communis Linn.-A review. Indian J. Nat. Prod. Resour. $2011,2,395-402$.

201. Amalraj, A.; Gopi, S. Biological activities and medicinal properties of Asafoetida: A review. J. Tradit. Complement. Med. 2017, 7, 347-359. [CrossRef] [PubMed]

202. Mahendra, P.; Bisht, S. Ferula asafoetida: Traditional uses and pharmacological activity. Pharmacogn. Rev. 2012, 6, 141-146. [CrossRef] [PubMed]

203. Toma, C.C.; Olah, N.K.; Vlase, L.; Mogoşan, C.; Mocan, A. Comparative studies on polyphenolic composition, antioxidant and diuretic effects of Nigella sativa L. (black cumin) and Nigella damascena L. (Lady-in-a-Mist) seeds. Molecules 2015, 20, 9560-9574. [CrossRef]

204. Ahmad, A.; Husain, A.; Mujeeb, M.; Khan, S.A.; Najmi, A.K.; Siddique, N.A.; Damanhouri, Z.A.; Anwar, F. A review on therapeutic potential of Nigella sativa: A miracle herb. Asian Pac. J. Trop. Biomed. 2013, 3, 337-352. [CrossRef]

205. Ghanbari, R.; Anwar, F.; Alkharfy, K.M.; Gilani, A.H.; Saari, N. Valuable Nutrients and Functional Bioactives in Different Parts of Olive (Olea europaea L.)—A Review. Int. J. Mol. Sci. 2012, 13, 3291-3340. [CrossRef] [PubMed] 
206. Karygianni, L.; Cecere, M.; Argyropoulou, A.; Hellwig, E.; Skaltsounis, A.L.; Wittmer, A.; Tchorz, J.P.; Al-Ahmad, A. Compounds from Olea europaea and Pistacia lentiscus inhibit oral microbial growth. BMC Complement. Altern. Med. 2019, 19, 51. [CrossRef]

207. Romani, A.; Ieri, F.; Urciuoli, S.; Noce, A.; Marrone, G.; Nediani, C.; Bernini, R. Health effects of phenolic compounds found in extra-virgin olive oil, by-products, and leaf of Olea europaea L. Nutrients 2019, 11, 1776. [CrossRef]

208. Abbasi-Maleki, S.; Kadkhoda, Z.; Taghizad-Farid, R. The antidepressant-like effects of Origanum majorana essential oil on mice through monoaminergic modulation using the forced swimming test. J. Tradit. Complement. Med. 2020, 10, 327-335. [CrossRef]

209. Algera, M.H.; Kamp, J.; van der Schrier, R.; van Velzen, M.; Niesters, M.; Aarts, L.; Dahan, A.; Olofsen, E. Opioid-induced respiratory depression in humans: A review of pharmacokinetic-pharmacodynamic modelling of reversal. Br. J. Anaesth. 2019, 122, e168-e179. [CrossRef]

210. Benyamin, R.; Trescot, A.M.; Datta, S.; Buenaventura, R.; Adlaka, R.; Sehgal, N.; Glaser, S.E.; Vallejo, R. Opioid complications and side effects. Pain Physician 2008, 11, 105-120. [CrossRef]

211. Gómez-Serranillos, M.P.; Palomino, O.M.; Carretero, E.; Villar, A. Analytical study and analgesic activity of oripavine from Papaver somniferum L. Phyther. Res. 1998, 12, 346-349. [CrossRef]

212. Sheng, S.; Huang, J.; Ren, Y.; Zhi, F.; Tian, X.; Wen, G.; Ding, G.; Xia, T.C.; Hua, F.; Xia, Y. Neuroprotection against Hypoxic/Ischemic Injury: $\delta$-Opioid Receptors and BDNF-TrkB Pathway. Cell. Physiol. Biochem. 2018, 47, 302-315. [CrossRef] [PubMed]

213. Shenoy, S.S.; Lui, F. Biochemistry, Endogenous Opioids. In StatPearls [Internet]; StatPearls: Treasure Island, FL, USA, 2021.

214. Johnston, J. Petasites hybridus Monograph. Altern. Med. Rev. 2001, 6, 207-209.

215. Farzaei, M.H.; Abbasabadi, Z.; Ardekani, M.R.S.; Rahimi, R.; Farzaei, F. Parsley: A review of ethnopharmacology, phytochemistry and biological activities. J. Tradit. Chin. Med. 2013, 33, 815-826. [CrossRef]

216. Shojaii, A.; Abdollahi Fard, M. Review of Pharmacological Properties and Chemical Constituents of Pimpinella anisum. ISRN Pharm. 2012, 2012, 510795. [CrossRef] [PubMed]

217. Ksouda, G.; Sellimi, S.; Merlier, F.; Falcimaigne-cordin, A.; Thomasset, B.; Nasri, M.; Hajji, M. Composition, antibacterial and antioxidant activities of Pimpinella saxifraga essential oil and application to cheese preservation as coating additive. Food Chem. 2019, 288, 47-56. [CrossRef]

218. Kumar, S.; Malhotra, S.; Prasad, A.; Eycken, E.; Bracke, M.; Stetler-Stevenson, W.; Parmar, V.; Ghosh, B. Anti-Inflammatory and Antioxidant Properties of Piper Species: A Perspective from Screening to Molecular Mechanisms. Curr. Top. Med. Chem. 2015, 15, 886-893. [CrossRef]

219. Damanhouri, Z.A. A Review on Therapeutic Potential of Piper nigrum L. (Black Pepper): The King of Spices. Med. Aromat. Plants 2014, 3, 161. [CrossRef]

220. Nahak, G.; Sahu, R.K. Phytochemical evaluation and antioxidant activity of Piper cubeba and Piper nigrum. J. Appl. Pharm. Sci. 2011, 1, 153-157.

221. Salehi, B.; Zakaria, Z.A.; Gyawali, R.; Ibrahim, S.A.; Rajkovic, J.; Shinwari, Z.K.; Khan, T.; Sharifi-Rad, J.; Ozleyen, A.; Turkdonmez, E.; et al. Piper Species: A Comprehensive Review on Their Phytochemistry, Biological Activities and Applications. Molecules 2019, 24, 1364. [CrossRef]

222. Bozorgi, M.; Memariani, Z.; Mobli, M.; Salehi Surmaghi, M.H.; Shams-Ardekani, M.R.; Rahimi, R. Five pistacia species (P. vera, P. atlantica, P. terebinthus, P. khinjuk, and P. lentiscus): A review of their traditional uses, phytochemistry, and pharmacology. Sci. World J. 2013, 2013, 219815. [CrossRef] [PubMed]

223. Nirumand, M.C.; Hajialyani, M.; Rahimi, R.; Farzaei, M.H.; Zingue, S.; Nabavi, S.M.; Bishayee, A. Dietary plants for the prevention and management of kidney stones: Preclinical and clinical evidence and molecular mechanisms. Int. J. Mol. Sci. 2018, 19, 765. [CrossRef] [PubMed]

224. Dar, P.A.; Sofi, G.; Jafri, M.A. Polypodium vulgare Linn. a versatile herbal medicine: A review. Int. J. Pharm. Sci. Res. 2012, 3, 1616-1620. [CrossRef]

225. Zhou, Y.X.; Xin, H.L.; Rahman, K.; Wang, S.J.; Peng, C.; Zhang, H. Portulaca oleracea L.: A review of phytochemistry and pharmacological effects. Biomed Res. Int. 2015, 2015, 925631. [CrossRef]

226. Tomczyk, M.; Leszczyńska, K.; Jakoniuk, P. Antimicrobial activity of Potentilla species. Fitoterapia 2008, 79, 592-594. [CrossRef]

227. Islam, N.U.; Amin, R.; Shahid, M.; Amin, M.; Zaib, S.; Iqbal, J. A multi-target therapeutic potential of Prunus domestica gum stabilized nanoparticles exhibited prospective anticancer, antibacterial, urease-inhibition, anti-inflammatory and analgesic properties. BMC Complement. Altern. Med. 2017, 17, 276. [CrossRef] [PubMed]

228. Arena, A.; Bisignano, C.; Stassi, G.; Filocamo, A.; Mandalari, G. Almond skin inhibits HSV-2 replication in peripheral blood mononuclear cells by modulating the cytokine network. Molecules 2015, 20, 8816-8822. [CrossRef] [PubMed]

229. Bottone, A.; Montoro, P.; Masullo, M.; Pizza, C.; Piacente, S. Metabolomics and antioxidant activity of the leaves of Prunus dulcis Mill (Italian cvs. Toritto and Avola). J. Pharm. Biomed. Anal. 2018, 158, 54-65. [CrossRef]

230. Gorji, N.; Moeini, R.; Memariani, Z. Almond, hazelnut and walnut, three nuts for neuroprotection in Alzheimer's disease: A neuropharmacological review of their bioactive constituents. Pharmacol. Res. 2018, 129, 115-127. [CrossRef]

231. Gilani, A.H.; Aziz, N.; Ali, S.M.; Saeed, M. Pharmacological basis for the use of peach leaves in constipation. J. Ethnopharmacol. 2000, 73, 87-93. [CrossRef]

232. Kumar, D. Anti-inflammatory, analgesic, and antioxidant activities of methanolic wood extract of Pterocarpus santalinus L. J. Pharmacol. Pharmacother. 2011, 2, 200-202. [CrossRef] 
233. Narayan, S.; Veeraraghavan, M.; Devi, C.S. Pterocarpus santalinus: An in vitro study on its anti-Helicobacter pylori effect. Phyther. Res. 2007, 21, 190-193. [CrossRef]

234. Neagu, E.; Radu, G.L.; Albu, C.; Paun, G. Antioxidant activity, acetylcholinesterase and tyrosinase inhibitory potential of Pulmonaria officinalis and Centarium umbellatum extracts. Saudi J. Biol. Sci. 2018, 25, 578-585. [CrossRef] [PubMed]

235. Al-Khalil, S.; Turabi, Z.; Musmar, M.; Yaish, S. Antispasmodic activity of Rosmarinus officinalis and Ruscus aculeatus. Bethlehem Univ. J. 2002, 21, 54-60.

236. Cai, Y.; Sun, M.; Xing, J.; Corke, H. Antioxidant phenolic constituents in roots of Rheum officinale and Rubia cordifolia: Structureradical scavenginq activity relationships. J. Agric. Food Chem. 2004, 52, 7884-7890. [CrossRef] [PubMed]

237. Chen, D.C.; Wang, L. Mechanisms of therapeutic effects of rhubarb on gut origin sepsis. Chin. J. Traumatol. (Engl. Ed.) 2009, 12, 365-369. [CrossRef]

238. Basim, E.; Basim, H. Antibacterial activity of Rosa damascena essential oil. Fitoterapia 2003, 74, 394-396. [CrossRef]

239. Cendrowski, A.; Krasniewska, K.; Przybył, J.L.; Zielinska, A.; Kalisz, S. Antibacterial and Antioxidant Activity of Extracts from Rose Fruits (Rosa rugosa). Molecules 2020, 25, 1365. [CrossRef]

240. Dolati, K.; Rakhshandeh, H.; Shafei, M.N. Effect of aqueous fraction of Rosa damascena on ileum contractile response of guinea pigs. Avicenna J. Phytomedicine 2013, 3, 248-253. [CrossRef]

241. Lattanzio, F.; Greco, E.; Carretta, D.; Cervellati, R.; Govoni, P.; Speroni, E. In vivo anti-inflammatory effect of Rosa canina L. extract. J. Ethnopharmacol. 2011, 137, 880-885. [CrossRef]

242. Mileva, M.; Ilieva, Y.; Jovtchev, G.; Gateva, S.; Zaharieva, M.M.; Georgieva, A.; Dimitrova, L.; Dobreva, A.; Angelova, T.; Vilhelmova-Ilieva, N.; et al. Rose flowers-A delicate perfume or a natural healer? Biomolecules 2021, 11, 127. [CrossRef] [PubMed]

243. Andrade, J.M.; Faustino, C.; García, C.; Ladeiras, D.; Reis, C.P.; Rijo, P. Rosmarinus officinalis L.: An update review of its phytochemistry and biological activity Joana. Futur. Sci. 2018, 4, FSO283. [CrossRef] [PubMed]

244. De Oliveira, J.R.; Esteves, S.; Camargo, A. Rosmarinus officinalis L. (rosemary) as therapeutic and prophylactic agent. J. Biomed. Sci. 2019, 8, 5. [CrossRef]

245. Karim, A.; Mekhfi, H.; Ziyyat, A.; Legssyer, A.; Bnouham, M.; Amrani, S.; Atmani, F.; Melhaoui, A.; Aziz, M. Anti-diarrhoeal activity of crude aqueous extract of Rubia tinctorum L. roots in rodents. J. Smooth Muscle Res. 2010, 46, 119-123. [CrossRef]

246. Van de Velde, F.; Esposito, D.; Grace, M.H.; Pirovani, M.E.; Lila, M.A. Anti-inflammatory and wound healing properties of polyphenolic extracts from strawberry and blackberry fruits. Food Res. Int. 2019, 121, 453-462. [CrossRef] [PubMed]

247. Kilic, I.; Yesiloglu, Y.; Bayrak, Y.; Gülen, S.; Bakkal, T. Antioxidant activity of Rumex conglomeratus P. Collected from turkey. Asian J. Chem. 2013, 25, 9683-9687. [CrossRef]

248. Orbán-Gyapai, O.; Liktor-Busa, E.; Kúsz, N.; Stefkó, D.; Urbán, E.; Hohmann, J.; Vasas, A. Antibacterial screening of Rumex species native to the Carpathian Basin and bioactivity-guided isolation of compounds from Rumex aquaticus. Fitoterapia 2017, 118, 101-106. [CrossRef]

249. Loonat, F.; Amabeoku, G.J. imboyek. Antinociceptive, anti-inflammatory and antipyretic activities of the leaf methanol extract of Ruta graveolens L. (Rutaceae) in mice and rats. Afr. J. Tradit. Complement. Altern. Med. 2014, 11, 173-181. [CrossRef]

250. Salman, H.A.; Venkatesh, S.; Senthilkumar, R.; Kumar, B.S.G.; Ali, A.M. Determination of antibacterial activity and metabolite profile of Ruta graveolens against Streptococcus mutans and Streptococcus sobrinus. J. Lab. Physicians 2018, 10, 320-325. [CrossRef]

251. Da Silva, I.B.; Rafaela Damasceno, S.; Maco, D.P.C.; Randau, K.P. Use of medicinal plants in the treatment of erysipelas: A review. Pharmacogn. Rev. 2018, 12, 200-207. [CrossRef]

252. Jabbari, M.; Daneshfard, B.; Emtiazy, M.; Khiveh, A.; Hashempur, M.H. Biological Effects and Clinical Applications of Dwarf Elder (Sambucus ebulus L.): A Review. J. Evid.-Based Complement. Altern. Med. 2017, 22, 996-1001. [CrossRef]

253. Jaradat, N.A.; Zaid, A.N.; Al-Ramahi, R.; Alqub, M.A.; Hussein, F.; Hamdan, Z.; Mustafa, M.; Qneibi, M.; Ali, I. Ethnopharmacological survey of medicinal plants practiced by traditional healers and herbalists for treatment of some urological diseases in the West Bank/Palestine. BMC Complement. Altern. Med. 2017, 17, 255. [CrossRef]

254. Quave, C.L.; Plano, L.R.W.; Bennett, B.C. Quorum sensing inhibitors of Staphylococcus aureus from Italian medicinal plants. Planta Med. 2011, 77, 188-195. [CrossRef]

255. Salehzadeh, A.; Asadpour, L.; Naeemi, A.S.; Houshmand, E. Antimicrobial activity of methanolic extracts of Sambucus ebulus and Urtica dioica against clinical isolates of methicillin resistant Staphylococcus aureus. Afr. J. Tradit. Complement. Altern. Med. 2014, 11, 38-40. [CrossRef]

256. Shokrzadeh, M.; Saeedi Saravi, S.S. The chemistry, pharmacology and clinical properties of Sambucus ebulus: A review. J. Med. Plants Res. 2010, 4, 95-103. [CrossRef]

257. Tasinov, O.; Kiselova-Kaneva, Y.; Ivanova, D. Sambucus ebulus-From traditional medicine to recent studies. Scr. Sci. Med. 2013, 45, 36. [CrossRef]

258. Harnett, J.; Oakes, K.; Carè, J.; Leach, M.; Brown, D.; Holger, C.; Pinder, T.-A.; Steel, A.; Anheyer, D. The effects of Sambucus nigra berry on acute respiratory viral infections: A rapid review of clinical studies. Adv. Integr. Med. 2020, 7, 240-246. [CrossRef] [PubMed]

259. ESCOP_European Scientific Cooperative of Phytotherapy. ESCOP Monographs—Sambuci Flos—Elder Flower, 3rd ed.; ESCOP, Ed.; Thieme Publishing Group: Stuttgard, Germany, 2013; ISBN 978-1-901964-11-0. 
260. Roxas, M.; Jurenka, J. Colds and influenza: A review of diagnosis and conventional, botanical, and nutritional considerations. Altern. Med. Rev. 2007, 12, 25-48. [PubMed]

261. Sargin, S.A. Potential anti-influenza effective plants used in Turkish folk medicine: A review. J. Ethnopharmacol. 2021, $265,113319$. [CrossRef]

262. Chen, X.; Li, B.; Gao, Y.; Ji, J.; Wu, Z.; Chen, S. Saponins from Sanguisorba officinalis improve hematopoiesis by promoting survival through FAK and Erk1/2 activation and modulating cytokine production in bone marrow. Front. Pharmacol. 2017, 8, 130. [CrossRef]

263. Misra, B.B.; Dey, S. Comparative phytochemical analysis and antibacterial efficacy of in vitro and in vivo extracts from East Indian sandalwood tree (Santalum album L.). Lett. Appl. Microbiol. 2012, 55, 476-486. [CrossRef] [PubMed]

264. Suganya, K.; Liu, Q.F.; Koo, B.S. Santalum album extract exhibits neuroprotective effect against the TLR3-mediated neuroinflammatory response in human SH-SY5Y neuroblastoma cells. Phyther. Res. 2021, 35, 1991-2004. [CrossRef]

265. Vivanco, J.M.; Tumer, N.E. Translation inhibition of capped and uncapped viral RNAs mediated by ribosome-inactivating proteins. Phytopathology 2003, 93, 588-595. [CrossRef]

266. Ayromlou, A.; Masoudi, S.; Mirzaie, A. Chemical composition, antioxidant, antibacterial, and anticancer activities of Scorzonera calyculata boiss. And Centaurea irritans wagenitz. Extracts, endemic to iran. J. Rep. Pharm. Sci. 2020, 9, 118-127. [CrossRef]

267. Küpeli Akkol, E.; Acikara, O.B.; Süntar, I.; Citolu, G.S.; Kele, H.; Ergene, B. Enhancement of wound healing by topical application of Scorzonera species: Determination of the constituents by HPLC with new validated reverse phase method. J. Ethnopharmacol. 2011, 137, 1018-1027. [CrossRef] [PubMed]

268. Sweidan, A.; El-Mestrah, M.; Kanaan, H.; Dandache, I.; Merhi, F.; Chokr, A. Antibacterial and antibiofilm activities of Scorzonera mackmeliana. Pak. J. Pharm. Sci. 2020, 33, 199-206. [CrossRef]

269. Seigner, J.; Junker-Samek, M.; Plaza, A.; D’Urso, G.; Masullo, M.; Piacente, S.; Holper-Schichl, Y.M.; De Martin, R. A Symphytum officinale root extract exerts anti-inflammatory properties by affecting two distinct steps of NF-kB signaling. Front. Pharmacol. 2019, 10, 289. [CrossRef]

270. Pareek, A.; Suthar, M.; Rathore, G.S.; Bansal, V. Feverfew (Tanacetum parthenium L.): A systematic review. Pharmacogn. Rev. 2011, 5, 103-110. [CrossRef]

271. Wider, B.; Pittler, M.H.; Ernst, E. Feverfew for preventing migraine. Cochrane Database Syst. Rev. 2015, 2015, CD002286. [CrossRef]

272. Rahimifard, M.; Navaei-Nigjeh, M.; Mahroui, N.; Mirzaei, S.; Siahpoosh, Z.; Nili-Ahmadabadi, A.; Mohammadirad, A.; Baeeri, M.; Hajiaghaie, R.; Abdollahi, M. Improvement in the function of isolated rat pancreatic islets through reduction of oxidative stress using traditional Iranian medicine. Cell J. 2014, 16, 147-162.

273. Gilani, A.H.; Bashir, S.; Memon, R. Antispasmodic and antidiarrheal activities of Valeriana hardwickii wall. Rhizome are putatively mediated through calcium channel blockade. Evid.-Based Complement. Altern. Med. 2011, 2011, 304960. [CrossRef]

274. Skalicka-Woźniak, K.; Walasek, M.; Aljarba, T.M.; Stapleton, P.; Gibbons, S.; Xiao, J.; Łuszczki, J.J. The anticonvulsant and anti-plasmid conjugation potential of Thymus vulgaris chemistry: An in vivo murine and in vitro study. Food Chem. Toxicol. 2018, 120, 472-478. [CrossRef]

275. Sun, Z.; Park, S.Y.; Hwang, E.; Zhang, M.; Seo, S.A.; Lin, P.; Yi, T.H. Thymus vulgaris alleviates UVB irradiation induced skin damage via inhibition of MAPK/AP-1 and activation of Nrf2-ARE antioxidant system. J. Cell. Mol. Med. 2017, 21, 336-348. [CrossRef]

276. Pundarikakshudu, K.; Shah, D.H.; Panchal, A.H.; Bhavsar, G.C. Anti-inflammatory activity of fenugreek (Trigonella foenum-graecum Linn) seed petroleum ether extract. Indian J. Pharmacol. 2016, 48, 441-444. [CrossRef]

277. Sharma, S.; Shrivastav, V.; Shrivastav, A.; Shrivastav, B. Therapeutic potential of wheatgrass (Triticum aestivum L.) for the treat-ment of chronic diseases. South Asian J. Exp. Biol. 2014, 3, 308-313. [CrossRef]

278. Salehi, B.; Shetty, M.S.; Anil Kumar, N.V.; Živković, J.; Calina, D.; Docea, A.O.; Emamzadeh-Yazdi, S.; Kılıç, C.S.; Goloshvili, T.; Nicola, S.; et al. Veronica plants-Drifting from farm to traditional healing, food application, and phytopharmacology. Molecules 2019, 24, 2454. [CrossRef]

279. Piana, M.; Silva, M.A.; Trevisan, G.; De Brum, T.F.; Silva, C.R.; Boligon, A.A.; Oliveira, S.M.; Zadra, M.; Hoffmeister, C.; Rossato, M.F.; et al. Antiinflammatory effects of Viola tricolor gel in a model of sunburn in rats and the gel stability study. J. Ethnopharmacol. 2013, 150, 458-465. [CrossRef]

280. Ahmad, B.; Azam, S.; Bashir, S.; Khan, I.; Adhikari, A.; Choudhary, M.I. Anti-inflammatory and enzyme inhibitory activities of a crude extract and a pterocarpan isolated from the aerial parts of Vitex agnus-castus. Biotechnol. J. 2010, 5, 1207-1215. [CrossRef]

281. Colombo, F.; Di Lorenzo, C.; Regazzoni, L.; Fumagalli, M.; Sangiovanni, E.; Peres De Sousa, L.; Bavaresco, L.; Tomasi, D.; Bosso, A.; Aldini, G.; et al. Phenolic profiles and anti-inflammatory activities of sixteen table grape (Vitis vinifera L.) varieties. Food Funct. 2019, 10, 1797-1807. [CrossRef] [PubMed]

282. Bazh, E.K.A.; El-Bahy, N.M. In vitro and in vivo screening of anthelmintic activity of ginger and curcumin on Ascaridia galli. Parasitol. Res. 2013, 112, 3679-3686. [CrossRef] [PubMed]

283. Haniadka, R.; Saldanha, E.; Sunita, V.; Palatty, P.L.; Fayad, R.; Baliga, M.S. A review of the gastroprotective effects of ginger (Zingiber officinale Roscoe). Food Funct. 2013, 4, 845-855. [CrossRef] [PubMed]

284. Siddaraju, M.N.; Dharmesh, S.M. Inhibition of gastric $\mathrm{H}^{+}, \mathrm{K}^{+}$-ATPase and Helicobacter pylori growth by phenolic antioxidants of Zingiber officinale. Mol. Nutr. Food Res. 2007, 51, 324-332. [CrossRef] 
285. Index Omnium Medicamentorum, E Compositionum, quae Reperiuntur in Aromataria Ve. Hospitalis Maioris Mediolani, ( ... ); Archivio Ospedale Maggiore, Servizio sanitario e di culto ex Archivio Bianco SAN524 (Ed.) 1711.

286. Index omnium Medicamentorum, E Compositionum, quae reperiuntur in Aromataria Ve. Hospitalis Maioris Mediolani, ( ... ); Archivio Ospedale Maggiore, Servizio sanitario e di culto ex Archivio Bianco SAN524 (Ed.) 1729.

287. Index Medicamentorum simplicium \& compositorum Ad usum Nosocomii Maioris Mediolani; Archivio Ospedale Maggiore, Servizio sanitario e di culto ex Archivio Bianco SAN524 (Ed.) 1760.

288. Articoli Provenienti da Piazze Estere; Archivio Ospedale Maggiore, Servizio sanitario e di culto ex Archivio Bianco SAN524 (Ed.) 1793.

289. Nuova Farmacopea ad uso Dell'ospedale civico di Milano, ed Annesso L.P. di Santa Corona; Archivio Ospedale Maggiore, Servizio sanitario e di culto ex Archivio Bianco SAN523 (Ed.) Tipografia Pulini in Cordusio: Milano, Italy, 1809.

290. Pharmacopoea Austriaca Oeconomiae Nosocomii Civici Generalis Mediolanensi adcomodata; Archivio Ospedale Maggiore, Direzione medica ex Archivio Rosso DIR579, Ed.; 1810-1820.

291. Pharmacopoea Austriaca. Tertia Editio Emendata; Archivio Ospedale Maggiore, Servizio sanitario e di culto ex Archivio Bianco SAN525, Ed.; Mediolani: Imp. Regiis Typis: Milano, Italy, 1819.

292. Pharmacopoea in usum Nosocomii Majoris Mediolanensis; Archivio Ospedale Maggiore, Direzione medica ex Archivio Rosso DIR578 (Ed.) 1839.

293. Pharmacopoea ad usum Nosocomii Civici Generalis Mediolanensis anno 1789-Milano: Mediolani; Bianchi e Motta: Milano, Italy, 1789 .

294. Mandegary, A.; Sayyah, M.; Reza Heidari, M. Antinociceptive and anti-inflammatory activity of the seed and root extracts of Ferula gummosa Boiss in mice and rats. Daru 2004, 12, 58-62.

295. Gupta, I.; Gupta, V.; Parihar, A.; Gupta, S.; Lüdtke, R.; Safayhi, H.; Ammon, H.P. Effects of Boswellia serrata gum resin in patients with bronchial asthma: Results of a double-blind, placebo-controlled, 6-week clinical study. Eur. J. Med. Res. 1998, 3, 511-514.

296. Ayromlou, A.; Masoudi, S.; Mirzaie, A. Scorzonera calyculata Aerial Part Extract Mediated Synthesis of Silver Nanoparticles: Evaluation of Their Antibacterial, Antioxidant and Anticancer Activities. J. Clust. Sci. 2019, 30, 1037-1050. [CrossRef]

297. Trescot, A.M.; Datta, S.; Lee, M.; Hans, H. Opioid pharmacology. Pain Physician 2008, 11, 133-154. [CrossRef] 